\title{
Tropical tropospheric ozone column retrieval for GOME-2
}

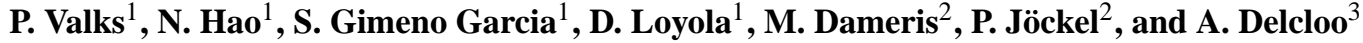 \\ ${ }^{1}$ Institut für Methodik der Fernerkundung (IMF), Deutsches Zentrum für Luft- und Raumfahrt (DLR), \\ Oberpfaffenhofen, Germany \\ ${ }^{2}$ Institut für Physik der Atmosphäre (IPA), Deutsches Zentrum für Luft- und Raumfahrt (DLR), Oberpfaffenhofen, Germany \\ ${ }^{3}$ Royal Meteorological Institute of Belgium (RMI), Brussels, Belgium
}

Correspondence to: P. Valks (pieter.valks@dlr.de)

Received: 19 December 2013 - Published in Atmos. Meas. Tech. Discuss.: 28 January 2014

Revised: 19 June 2014 - Accepted: 19 June 2014 - Published: 14 August 2014

\begin{abstract}
This paper presents the operational retrieval of tropical tropospheric ozone columns (TOCs) from the Second Global Ozone Monitoring Experiment (GOME-2) instruments using the convective-cloud-differential (CCD) method. The retrieval is based on total ozone and cloud property data provided by the GOME Data Processor (GDP) 4.7, and uses above-cloud and clear-sky ozone column measurements to derive a monthly mean TOC between $20^{\circ} \mathrm{N}$ and $20^{\circ} \mathrm{S}$. Validation of the GOME-2 TOC with several tropical ozonesonde sites shows good agreement, with a high correlation between the GOME- 2 and sonde measurements, and small biases within $\sim 3 \mathrm{DU}$. The TOC data have been used in combination with tropospheric $\mathrm{NO}_{2}$ measurements from GOME-2 to analyse the effect of the 20092010 El Niño-Southern Oscillation (ENSO) on the tropospheric ozone distribution in the tropics. El Niño induced dry conditions in September-October 2009 resulted in relatively high tropospheric ozone columns over the southern Indian Ocean and northern Australia, while La Niña conditions in September-October 2010 resulted in a strong increase in tropospheric $\mathrm{NO}_{2}$ in South America, and enhanced ozone in the eastern Pacific and South America. Comparisons of the GOME-2 tropospheric ozone data with simulations of the ECHAM/MESSy Atmospheric Chemistry (EMAC) model for 2009 El Niño conditions illustrate the usefulness of the GOME-2 TOC measurements in evaluating chemistry climate models (CCMs). Evaluation of CCMs with appropriate satellite observations helps to identify strengths and weaknesses of the model systems, providing a better understanding of driving mechanisms and adequate relations and feedbacks in the Earth atmosphere, and finally leading to improved models.
\end{abstract}

\section{Introduction}

Ozone in the tropical troposphere plays various important roles. It plays a key role in the global oxidizing power of the atmosphere as the main source of $\mathrm{OH}$, the most important oxidant in the troposphere (Thompson, 1992). Near the surface, excessive amounts of ozone are toxic to ecosystems, animals and man. Upper tropospheric ozone acts as a greenhouse gas by absorbing long-wave terrestrial radiation (Lacis et al., 1990; Foster and Shine, 1997).

Satellite observations offer the possibility to measure the distribution of tropospheric ozone over large areas and to study its large-scale temporal and spatial variability. This is of great importance, since ozone which is formed over regions where large amounts of ozone precursors are emitted can be transported over great distances and affect areas far from the source (Thompson et al., 2001).

Tropical tropospheric ozone has been inferred from a number of instruments, including GOME (Burrows et al., 1999), SCIAMACHY (Bovensmann et al., 1999), IASI (Clerbaux et al., 2009), OMI (Levelt et al., 2006) and MLS (Waters et al., 2006). Several techniques have been used to retrieve tropospheric ozone columns, such as the tropospheric ozone residual (TOR) method using OMI total ozone and MLS stratospheric ozone column measurements (Ziemke et al., 2006; Schroeberl et al., 2007), the direct retrieval of tropospheric ozone (e.g. Liu et al., 2010; Miles et al., 2014; Tuinder et al., 2013; Safieddine et al., 2013), and limb-nadirmatching observations from SCIAMACHY (Ebojie et al., 2014). Recently, also the multi-spectral retrieval of IASI thermal infrared and GOME-2 ultra-violet measurements has been demonstrated (Cuesta et al., 2013). 
In this paper, we describe the retrieval of the tropospheric ozone column (TOC) from GOME-2 measurements for the tropical region using the convective-cloud-differential (CCD) method. The original CCD method developed by Ziemke et al. (1998) uses TOMS (for the period 1979-2005) and OMI (for 2004 onwards) total ozone measurements over bright, high-altitude clouds in the tropical western Pacific to obtain an above-cloud stratospheric ozone amount. In this region, bright clouds are often associated with strong convective outflows and cloud tops in the upper troposphere. The tropical TOC is derived at cloud-free pixels by subtracting the stratospheric ozone amount from TOMS and OMI total ozone, assuming a zonally invariant stratospheric column. The CCD method can only be applied in the tropics where the assumption of a zonally invariant stratospheric column is valid. An improved CCD method has been developed by Valks et al. (2003) that is based on total ozone and cloud measurements from GOME. In contrast to TOMS, GOME is able to determine cloud fraction, cloud pressure and cloud albedo (optical thickness) by using measurements in the visible and near-infrared wavelength region. The CCD method has been further developed for the retrieval of tropical TOCs from GOME-2 within the framework of EUMETSAT's Satellite Application Facility on Ozone and Atmospheric Chemistry Monitoring (O3M-SAF). The GOME-2 instrument (Callies et al., 2000), launched aboard the MetOp-A and -B satellites, observes about four times smaller ground pixels than its predecessor GOME and provides an almost global coverage on a daily basis. Tropical TOCs have been retrieved for the period 2007-2013 using both GOME-2/A and GOME2/B measurements. We assess the accuracy of the GOME2 tropical TOCs with ozonesonde measurements from the Southern Hemisphere Additional Ozonesondes (SHADOZ) network (Thompson et al., 2003a), and we study the effect of the 2009-2010 El Niño-Southern Oscillation (ENSO) on the tropospheric ozone distribution. Furthermore, we examine the tropospheric $\mathrm{NO}_{2}$ distribution in the tropics from GOME2 measurements. Tropospheric $\mathrm{NO}_{2}$ columns provide valuable information on $\mathrm{NO}_{\mathrm{x}}$ emissions, and are useful to understand the effect of temporal and spatial variations in $\mathrm{NO}_{\mathrm{x}}$ emissions on the tropical tropospheric ozone distribution in the tropics. Finally, we illustrate the use of GOME-2 tropospheric ozone measurements in evaluating the chemistry climate model (CCM) EMAC (Jöckel et al., 2010). This exercise provides some insight into the possibilities of using this comprehensive data set to help to assess the quality of model results; it is the foundation for improving our understanding of processes driving atmospheric changes.

This paper is organized as follows. First, we give an overview of the GOME-2 satellite instrument and the operational data processing. Section 3 describes the GOME-2 total ozone and cloud products as used in the CCD algorithm, and the GOME-2 tropospheric $\mathrm{NO}_{2}$ columns examined in this study. In Sect. 4, the retrieval of tropical TOCs from GOME-2 with the CCD method is described, and the validity of the method is analysed. In Sect. 5, exemplary results of the GOME-2 TOCs are shown, and the effect of the 20092010 ENSO on the tropical tropospheric ozone and $\mathrm{NO}_{2}$ distribution is examined. Section 6 focuses on the validation of the GOME-2 tropical TOCs with ozonesonde measurements, and in Sect. 7 the potential of GOME-2 tropospheric ozone measurements in evaluating EMAC CCM simulations is analysed. The paper ends with a summary and concluding remarks.

\section{The GOME-2 instrument}

The Second Global Ozone Monitoring Experiment (GOME2) instruments were launched on-board the MetOp-A and MetOp-B satellites in October 2006 and September 2012, respectively, and are part of the EUMETSAT Polar System (EPS). The MetOp satellites are flying on a sun-synchronous orbit with an equator crossing time of 09:30 LT (descending node) and a repeat cycle of 29 days. The GOME2 instruments continue the long-term monitoring of atmospheric trace gases, including $\mathrm{O}_{3}$ and $\mathrm{NO}_{2}$, started by GOME (launched on ESA's ERS-2 platform in 1995) and continued with SCIAMACHY (launched on ESA's ENVISAT platform in 2002). GOME-2 is an improved version of the GOME instrument on the ERS-2 satellite (Callies et al., 2000; Munro et al., 2006). It is a nadir-scanning UV-VIS-NIR spectrometer with four main optical channels, covering the spectral range between 240 and $790 \mathrm{~nm}$ with a spectral resolution between 0.26 and $0.51 \mathrm{~nm}$ (FWHM). Additionally, two polarization components are measured with polarization measurement devices (PMDs) at 30 broad-band channels covering the full spectral range.

The default swath width of the GOME-2 scan is $1920 \mathrm{~km}$, which enables global coverage in about 1.5 days. The along-track dimension of the instantaneous field of view is $\sim 40 \mathrm{~km}$, while the across-track dimension depends on the integration time used for each channel. For the default $1920 \mathrm{~km}$ swath and the default integration time of $187.5 \mathrm{~ms}$, the ground pixel size is $80 \times 40 \mathrm{~km}^{2}$ (across-track $\times$ alongtrack) in the forward scan. Owing to a non-linear movement of the scan mirror, the ground pixel size remains nearly constant over the full scan. Since July 2013, the two GOME-2 instruments have been operated in tandem providing global coverage on a daily basis: GOME-2 on MetOp-A measures with a reduced swath width of $960 \mathrm{~km}$ and a smaller ground pixel size of $40 \times 40 \mathrm{~km}^{2}$ (forward scan), while GOME-2 on MetOp-B measures in default mode (i.e. $1920 \mathrm{~km}$ swath and ground pixel size of $80 \times 40 \mathrm{~km}^{2}$ ).

\subsection{Data processing}

The GOME-2 tropical TOC described in this paper is a level3 product, and has been developed by the German Aerospace Center (DLR) in the framework of EUMETSAT's Satellite 
Application Facility on Ozone and Atmospheric Chemistry Monitoring (O3M-SAF). The focus of the O3M-SAF is to process, archive, validate and disseminate atmospheric data products of ozone, $\mathrm{NO}_{2}$ and other trace gases, aerosols and surface ultraviolet radiation (http://o3msaf.fmi.fi).

The first step in the processing chain is the production of calibrated and geo-located level 1 radiances (level 0-to-1 processing). Level 1 products are generated operationally in the Core Ground Segment (CGS) at EUMETSAT headquarters in Darmstadt, Germany, and are broadcast via the EUMETCast system to the O3M-SAF processing facility in DLR, Germany. The DLR multi-mission payload ground segment system (Heinen et al., 2009) controls the reception, processing, archiving, ordering and dissemination of the GOME2 trace gas column products. The GOME-2 level-1 products are processed with the UPAS (Universal Processor for UV/VIS Atmospheric Spectrometers) system, a new generation system for the operational processing of trace gas and cloud property products (Valks et al., 2013).

The GOME-2 level-2 and -3 products are available via the GOME portal at DLR (http://atmos.caf. dlr.de/gome2), and can also be ordered via the O3MSAF portal (http://o3msaf.fmi.fi) and EUMETSAT portal (http://navigator.eumetsat.int).

\section{GOME-2 trace gases and cloud measurements}

\subsection{GOME-2 total ozone}

The total ozone columns are retrieved from the ratio of the Earthshine and Sunshine spectra measured by GOME-2 and utilizing the characteristic ozone spectral absorption features in a part of the Huggins ozone absorption band (325$335 \mathrm{~nm}$ ). The retrieval is performed with the GOME Data Processor (GDP) version 4.7 (Hao et al., 2014), the latest incarnation of the GDP 4 algorithm (Van Roozendael et al., 2006; Loyola et al., 2011). The algorithm employs the twostep Differential Optical Absorption Spectroscopy (DOAS) method (Platt and Stutz, 2008), with slant column fitting followed by air mass factor conversion to the vertical column density. The slant column fitting is based on Beer's law for trace gas absorption, and includes a polynomial closure term to deal with broadband signatures over the $325-335 \mathrm{~nm}$ fitting window. The fitting includes amplitudes for the effective temperature of the ozone absorption, $\mathrm{NO}_{2}$ absorption and for spectral interference signatures (instrumental undersampling, Ring-effect filling-in of solar Fraunhofer features), and a provision for earthshine/solar spectra wavelength registration offsets. In the retrieval, the use of Daumont-BrionMalicet ozone cross sections (Malicet et al., 1995; Brion et al., 1998) convolved with the GOME-2 instrument slit function (Siddans et al., 2006) provides the most consistent and stable results for GOME-2 (Hao et al., 2014).
Air mass factors are calculated on-line with the multiplescattering radiative transfer code LIDORT (Spurr, 2008). Optical property setups for the air mass factor computations are based on the TOMS V8 ozone profile climatology classified by total column (McPeters et al., 2007), and the assumption of a Rayleigh scattering atmosphere. The air mass factors are computed at a single wavelength of $325.5 \mathrm{~nm}$ (Van Roozendael et al., 2006). The vertical column $V$ and the air mass factors are adjusted iteratively to reflect the DOAS slant column result using the relation

$$
V=\frac{S / M+\Phi G A_{\text {cloud }}}{(1-\Phi) A_{\text {clear }}+\Phi A_{\text {cloud }}},
$$

where $S$ is the DOAS-retrieved slant column, $A_{\text {clear }}$ the clearsky air mass factor, $A_{\text {cloud }}$ the air mass factor for the atmosphere down to the cloud-top level, the "ghost column" $G$ is the quantity of ozone below the cloud-top height and $\Phi$ is the cloud radiance fraction. This relation assumes the independent pixel approximation (IPA) for partially cloudy and cloud-filled scenes), with clouds treated as Lambertian equivalent reflectors. GDP 4 includes a molecular Ring correction $M$, dependent on the total air mass factor, that is applied to the slant column to deal with distortion of ozone absorption features due to inelastic rotational Raman scattering effects (Van Roozendael et al., 2006).

The cloud properties to determine the cloud radiance fraction $\Phi$ and the cloudy air mass factor $A_{\text {cloud }}$ are retrieved from GOME-2 measurements using the OCRA (cloud fraction) and ROCINN (cloud pressure and albedo) algorithms (Loyola et al., 2007, see Sect. 3.3 in this paper). The cloud radiance fraction $\Phi$ is defined as

$\Phi=\frac{c_{\mathrm{f}} I_{\text {cloud }}}{\left(1-c_{\mathrm{f}}\right) I_{\text {clear }}+c_{\mathrm{f}} I_{\text {cloud }}}$,

where $c_{\mathrm{f}}$ is the cloud fraction, $I_{\text {clear }}$ and $I_{\text {cloud }}$ are the backscattered radiances for cloud-free and cloud-covered scenes, respectively. $I_{\text {clear }}$ and $I_{\text {cloud }}$ are calculated with the LIDORT radiative transfer model (at $325.5 \mathrm{~nm}$ ), and depend mainly on the surface and cloud albedos and on the GOME-2 viewing geometry. In the total ozone algorithm, the ghost column $G$ (the amount of ozone below the cloud top, which cannot be detected by GOME-2) is derived from the TOMS V8 ozone profile climatology using an empirical intra-cloud correction (Loyola et al., 2011). For the GOME-2/CCD method, this ghost column correction is not included, since the ozone column above the cloud is required:

$V_{\text {above cloud }}=\frac{S / M}{A_{\text {cloud }}}$.

\subsection{GOME-2 tropospheric $\mathrm{NO}_{2}$ column}

The tropospheric $\mathrm{NO}_{2}$ algorithm for GOME-2, as implemented in the GOME Data Processor (GDP) version 4.7, consists of several retrieval steps, as described in Valks et 
al. (2011). First, the DOAS method is used to determine $\mathrm{NO}_{2}$ slant column densities from calibrated GOME-2 (ir)radiance data in the $425-450 \mathrm{~nm}$ wavelength range, and initial total $\mathrm{NO}_{2}$ columns are computed using an air mass factor based on a stratospheric $\mathrm{NO}_{2}$ profile climatology (Lambert et al., 2000). Then a spatial filtering method is used to obtain the stratospheric $\mathrm{NO}_{2}$ component from the initial total $\mathrm{NO}_{2}$ column. After the stratosphere-troposphere separation, the tropospheric $\mathrm{NO}_{2}$ column can be determined by subtracting the stratospheric component from the total $\mathrm{NO}_{2}$ slant column, and applying a tropospheric air mass factor. For the tropospheric air mass factor computation, monthly average $\mathrm{NO}_{2}$ profiles from the MOZART-2 chemistry transport model are used, determined for the satellite overpass time. GOME-2 derived cloud properties, determined with the OCRA and ROCINN algorithms (see next section) are used to calculate the air mass factors for scenarios in the presence of clouds. For this study, monthly mean tropospheric $\mathrm{NO}_{2}$ fields on a $1^{\circ} \times 1^{\circ}$ grid have been calculated from orbit-based (level-2) GOME-2 data with cloud radiance fractions $\leq 0.5$, as provided by the GDP 4.7 .

\subsection{Cloud properties}

The OCRA and ROCINN algorithms (Loyola et al., 2007) are used for obtaining GOME-2 cloud information: OCRA provides the radiometric cloud fraction using the broad-band polarization UVN measurements, and ROCINN provides effective cloud pressure and cloud albedo from measurements in and adjacent to the oxygen A-band around $760 \mathrm{~nm}$.

With GOME-2, several improvements have been incorporated in the cloud algorithms. The initial ROCINN algorithm was based on scalar radiative transfer calculations in the oxygen A-band, without taking into account scattering by molecules and particles. ROCINN version 2.0, as used for GOME-2, is based on vector radiative transfer simulations taking into account Rayleigh scattering. Note that the cloud model used in the ozone and $\mathrm{NO}_{2}$ retrieval as described in Sects. 3.1 and 3.2 is consistent with the cloud model used in the OCRA/ROCINN cloud retrieval, in the sense that both use the IPA representing clouds as opaque Lambertian surfaces (Antón and Loyola, 2011). Another important upgrade for GOME-2 is the ability to distinguish clouds in measurements affected by ocean surface sun-glint, a phenomenon that is common at the edges of the GOME-2 swath. OCRA discriminates clouds in the region affected by sun-glint by analysing the broad-band polarization measurements (Loyola et al., 2011).

The above-cited studies about OCRA/ROCINN focused on mid-latitude cloud systems and the influences of clouds on the total ozone retrieval. Here, we focus on deep-convective clouds in the tropics as used in the GOME-2 CCD algorithm. Figure 1 shows maps of frequency of occurrence of deepconvective clouds as derived from OCRA/ROCINN, for January and July 2008. To obtain the figure, we classified clouds as deep convective if the effective cloud pressure is above the $300 \mathrm{hPa}$ level, the cloud albedo larger than 0.75 , and their cloud fraction exceeds 0.8. The patterns in Fig. 1 show the structure of the inter-tropical convergence zone (ITCZ) and the seasonal migration of the ITCZ. The eastern part of the tropical Indian Ocean and western part of the tropical Pacific have the highest frequency of deep-convective clouds. Particularly apparent are the large latitudinal shifts over South America, Africa and the South Asian subcontinent. These patterns agree well with the monthly averaged ISCCP (International Satellite Cloud Climatology Project) D2 data (Rossow and Schiffer, 1999) and the ITCZ climatology based on the High Reflectivity Cloud (HRC) data set (Waliser and Gautier, 1993).

The top panels of Fig. 2 show the frequency distributions of cloud pressures from GOME-2 over the tropical Indian Ocean and western Pacific as derived by ROCINN for January and July 2008. For comparison, the frequency distributions of the ISCCP-D2 cloud top pressures are shown as well. There is a good agreement between the ROCINN and ISCCP-D2 cloud pressure distributions, and both data sets indicate that the monthly mean pressures of tropical convective cloud are between 200 and $400 \mathrm{hPa}$ in the highly convective areas over the Indian Ocean and western Pacific. These results confirm the good agreement between the cloud properties derived from ROCINN using GOME/ERS-2 and ISCCP (Loyola et al., 2010). These cloud levels are more than $100 \mathrm{hPa}$ below the tropopause, which is located around $100 \mathrm{hPa}$ in the tropics. This is in agreement with other studies that suggest that most convective cloud tops do not extend up to the tropopause, but to the bottom of the tropical transition layer (Folkins et al., 1999; Fueglistaler et al., 2009), several kilometres below the tropopause. Furthermore, the effective (also called optical centroid) cloud pressure derived from VIS and NIR (oxygen A-band) satellite measurements using the Lambertian cloud model lies well below the physical cloud top pressure (Joiner et al., 2012; Ziemke et al., 2009a). The bottom panels of Fig. 2 show the frequency distributions of the cloud albedos as derived by ROCINN. The retrieved GOME- 2 cloud albedos are mostly between 0.6 and 0.85 , illustrating the high reflectivity of tropical convective clouds in the visible wavelength range.

\section{Tropical tropospheric ozone retrieval from GOME-2}

\subsection{GOME-2 CCD method}

The tropical TOC have been retrieved from GOME-2 measurements using the CCD method. In the first step, cloudy GOME-2 measurements with cloud fraction $f \geq 0.8$, cloud albedo $a_{\mathrm{c}} \geq 0.75$, and cloud top pressure $p_{\mathrm{c}} \leq 300 \mathrm{hPa}$ are used to determine the above-cloud ozone column (above $\sim 200 \mathrm{hPa}$, including the ozone column in the stratosphere and the tropical transition layer), as illustrated in Fig. 3. 

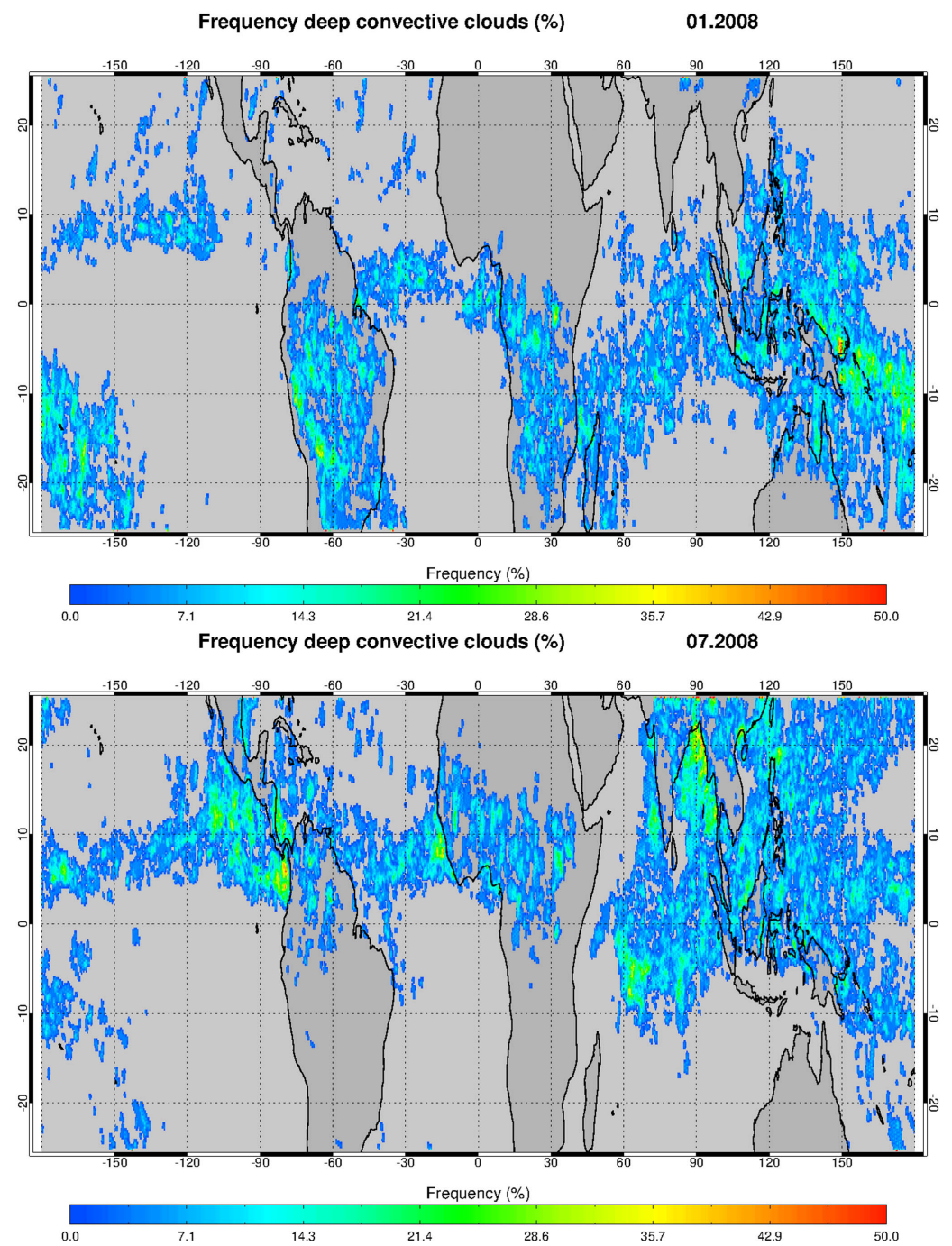

Figure 1. Frequency of occurrence of deep-convective clouds as derived from GOME-2 oxygen A band measurements using the OCRA/ROCINN algorithm. Results are shown for (top) January 2008 and (bottom) July 2008. Clouds are classified as deep convective if their tops are above the $300 \mathrm{hPa}$ level, the cloud albedo larger than 0.75 , and their cloud fraction exceeds 0.8 .

The cloudy GOME-2 measurements are selected from tropical measurements over the highly convective eastern Indian Ocean and the western Pacific $\left(70^{\circ} \mathrm{E}-170^{\circ} \mathrm{W}\right)$, where the greatest frequency of high level and high albedo clouds is found. The above-cloud ozone column is determined using Eq. (3).

As described in the previous section, the GOME-2 cloud pressures for the tropical convective clouds, as determined with OCRA/ROCINN, are between 200 and $400 \mathrm{hPa}$. To be able to calculate a consistent tropospheric ozone column with the CCD method, above-cloud ozone columns are derived for a fixed pressure level of $200 \mathrm{hPa}$. To that end, a small correction has been made for the difference between the cloud pressure level and the $200 \mathrm{hPa}$ level (typically $0-2 \mathrm{DU}$ ), assuming a constant (small) ozone volume mixing ratio of 5 ppbv (see Sect. 4.2). After this correction, the stratospheric ozone columns are monthly averaged for $1.25^{\circ}$ latitude bands between $20^{\circ} \mathrm{N}$ and $20^{\circ} \mathrm{S}$. Hereby, it is assumed that the stratospheric ozone column is independent of longitude in a given latitude band. The number of cloudy GOME-2 pixels with $f \geq 0.8$ and $p_{\mathrm{c}} \leq 300 \mathrm{hPa}$ varies between $150-800$ per month for each $\left(1.25^{\circ}\right)$ latitude band. Although this number is less than $2 \%$ of all the GOME-2 measurements, it is sufficiently large to provide an adequate statistical mean for the stratospheric ozone column. Because of the seasonal migration of the ITCZ, the region of tropical air shows a seasonal displacement as well. Periodically, sub-tropical air is present in the outer latitude bands $\left(15-20^{\circ} \mathrm{N}\right.$ or $\left.15-20^{\circ} \mathrm{S}\right)$, resulting in a small number of deep-convective cloud tops and an increased zonal variation in the derived stratospheric ozone column, especially within in the $15-20^{\circ} \mathrm{N}$ latitude band. In those cases, the northern (or southern) boundary 

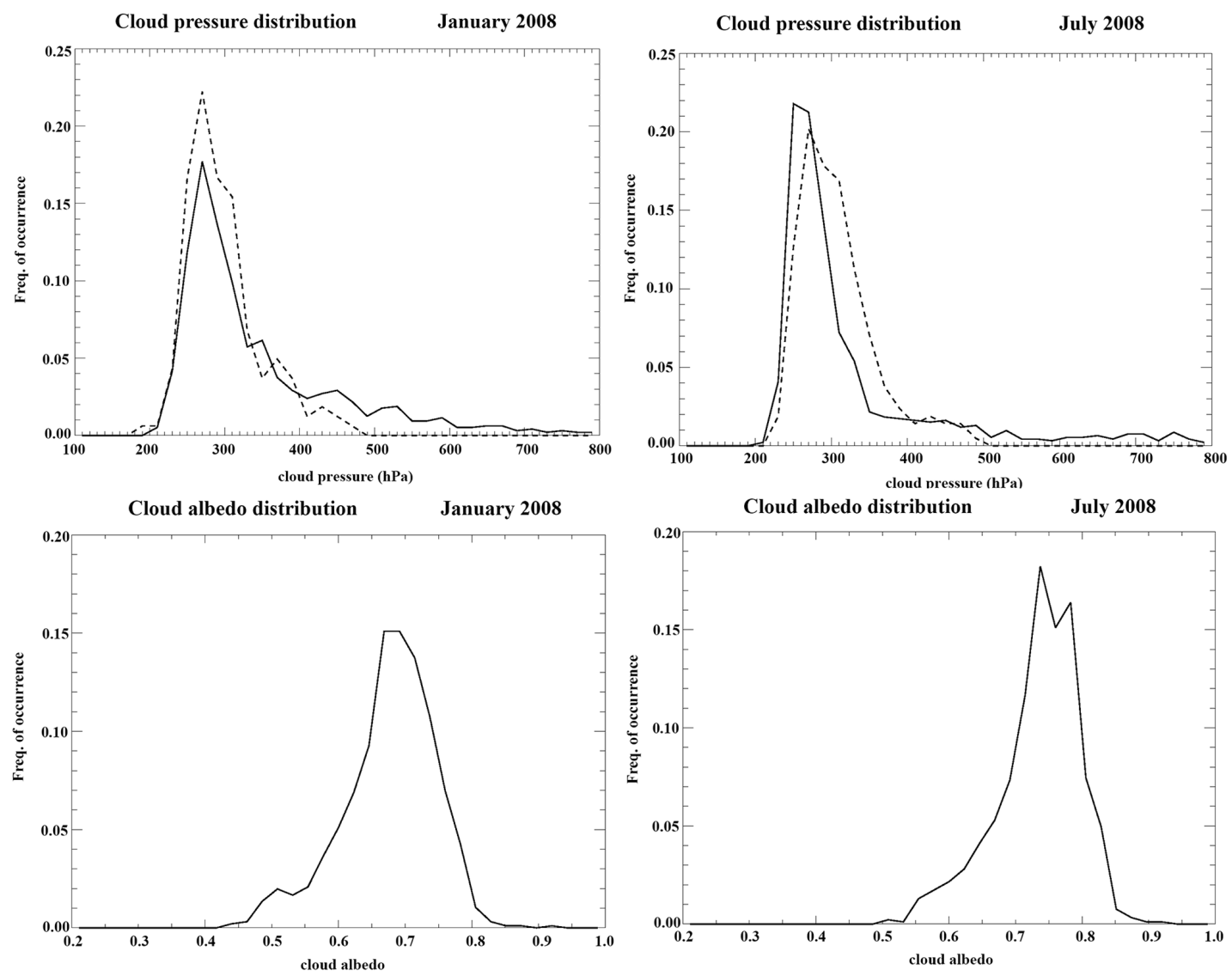

Figure 2. Histograms of ROCINN cloud pressures (top) and cloud albedos (bottom) for the area $12.5^{\circ} \mathrm{S}-12.5^{\circ} \mathrm{N} / 70^{\circ} \mathrm{E}-170^{\circ} \mathrm{W}$. Cloud top pressure from ISCCP-D2 has been plotted as well (dashed line). The ROCINN and ISCCP cloud data have been spatially averaged on a $2.5^{\circ}$ latitude by $2.5^{\circ}$ longitude grid, and then the relative number of grid cells has been plotted as a function of cloud pressure and cloud albedo. Results are shown for (left) January 2008 and (right) July 2008. ROCINN and ISCCP-D2 cloud pressure distributions are in good agreement (see Sect. 3.3 for an explanation of the plots).

for the GOME-2/CCD analysis will be limited to lower latitudes. To determine the valid latitude region, a lower limit for the number of cloudy GOME-2 measurements, and an upper limit for the SD in the above-cloud ozone columns is used. In the equatorial region between $12.5^{\circ} \mathrm{N}$ and $12.5^{\circ} \mathrm{S}$, the CCD method can be applied without any restrictions: the number of cloudy GOME-2 measurements (with $f \geq 0.8$ and $p_{\mathrm{c}} \leq 300 \mathrm{hPa}$ ) for each latitude band in the eastern Indian Ocean/ Western Pacific is larger than 300, and the $\mathrm{SD}<5 \mathrm{DU}$. In the latitude bands pole-wards of $12.5^{\circ} \mathrm{N}$ and $12.5^{\circ} \mathrm{S}$, the number of cloudy GOME-2 measurements can be significantly smaller and the SD in the above-cloud ozone columns increases, especially during the winter months. For the GOME-2/CCD analysis, a lower limit of 50 for the number of cloudy GOME-2 measurements and an upper limit of $5 \mathrm{DU}$ for the SD is used. Only when these criteria are met is the CCD method applied for the corresponding latitude band.

In the second step, cloud-free GOME-2 measurements $(f \leq 0.1)$ are used to determine the total ozone column. In the case of cloud-free pixels, GOME-2 is able to detect ozone in both the stratosphere and the troposphere. About half of the total number of GOME-2 measurements in the tropics are cloud-free $(f \leq 0.1)$. The total ozone columns are monthly averaged on a $1.25^{\circ}$ latitude by $2.5^{\circ}$ longitude grid. In a last step, the zonal mean stratospheric ozone column is subtracted from the gridded total ozone values, resulting in the monthly mean TOC.

The CCD method has been applied to GOME-2 data from both MetOp-A (from January 2007 onwards) and MetOp-B (from January 2013 onwards). There is a good agreement between the TOC data retrieved with the two instruments (see also Sect. 5). However, GOME-2B shows a small negative offset of 1-2 DU compared to GOME-2A, which is most likely related to a small negative bias in the GOME-2B total ozone columns for cloud-free conditions (currently under investigation).

An important advantage of the CCD method is that it is insensitive to the GOME-2 instrument degradation. As discussed in Hao et al. (2014), the degradation of the GOME-2 instrument has only a small effect on the level-2 total ozone 


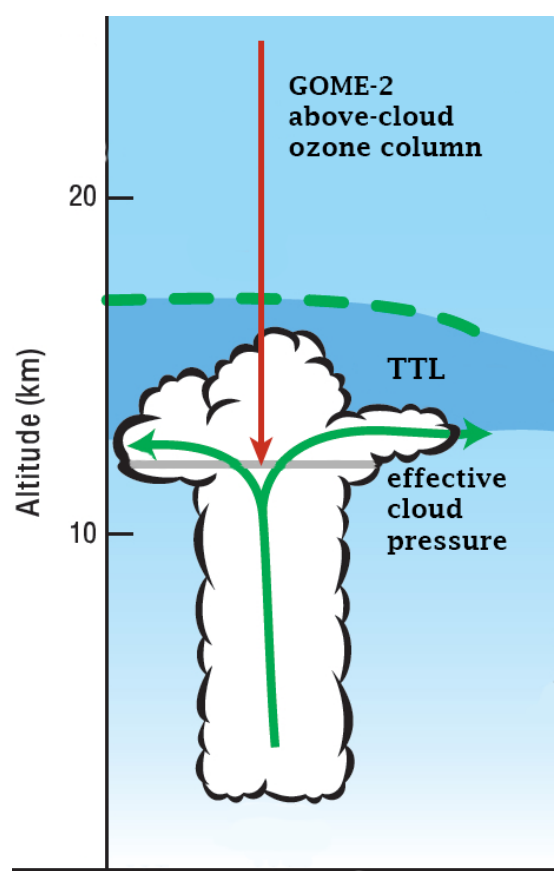

Figure 3. Schematic illustration of above-cloud ozone column measurements from GOME-2 for the tropics as used in the CCD technique. For tropical deep convective clouds, the effective cloud pressures as determined with GOME-2 are usually between 9.5$12.5 \mathrm{~km}$. TTL denotes the tropical transition layer below the tropopause (dashed green line). GOME-2 measurements with cloud fraction $\geq 0.8$, cloud albedo $\geq 0.75$ and cloud pressure $\leq 300 \mathrm{hPa}$ are used to determine the above-cloud ozone column.

columns retrieved with the GDP v4.7. Furthermore, the tropospheric ozone column is derived from the difference between cloud-free and cloudy GOME-2 ozone column measurements, which further reduces the effect of a possible degradation of the total ozone columns.

\subsection{Variability in stratospheric and upper tropospheric ozone}

An important assumption made in the CCD method is that the stratospheric ozone column is independent of longitude in the tropics. This assumption is based upon results of many years of ozone measurements from satellites and ozonesondes, as described below.

In Valks et al. (2003) comparisons of the CCD method for the GOME/ERS-2 instrument with stratospheric ozone columns based on ozonesonde data from the SHADOZ network have been made. The monthly mean stratospheric ozone columns derived with the GOME CCD method have been compared with ozonesonde measurements for eight tropical sites. A good agreement was found for these sites: the biases between the stratospheric ozone columns derived from GOME and the ozonesonde measurements are within the $3 \mathrm{DU}$ range and the rms differences at the sonde sites lie between 4 and 7 DU. A similar comparison for GOME2/MetOp-A using SHADOZ ozonesonde data for the period 2007-2012 (see Sect. 6) reveals comparable biases within the $3 \mathrm{DU}$ range and rms differences between 3 and $7 \mathrm{DU}$ (not shown). Comparisons of the TOMS/CCD method with SAGE II stratospheric ozone data have been made by Ziemke et al. (2005). For the tropical region between $20^{\circ} \mathrm{N}-20^{\circ} \mathrm{S}$, the bias between the TOMS and SAGE stratospheric column is in the $1-4 \mathrm{DU}$ range, while the rms differences average around 4-5 DU. In Ziemke et al. (2009a, 2010) comparisons have been made between the OMI stratospheric column derived from a cloud slicing method and MLS stratospheric ozone. They found a very good agreement with a small mean difference of 1-3 DU and a zonal rms difference of 2-3 DU. These studies show that the assumption that the monthly mean stratospheric ozone column is invariant with longitude has sufficient validity to derive a tropical tropospheric ozone column with the CCD method that contains valuable information about the tropospheric ozone variability. As discussed in Sect. 4.1, the assumption of a zonally invariant stratospheric column is not valid when sub-tropical air is present at the latitude boundaries around $20^{\circ} \mathrm{N}$ or $20^{\circ} \mathrm{S}$. In this case, the CCD method cannot be applied at these latitudes.

Another important assumption made in the original CCD method (Ziemke et al., 1998) is that UV measuring instruments such as GOME-2 only measure the ozone above the tops of highly reflective clouds, and that Eq. (3) can be used to determine the above-cloud ozone column. However, radiative transfer simulations show that there is also UV photon penetration and ozone absorption within deep convective clouds (Kokhanovsky and Rozanov, 2008; Ziemke et al., 2009a). The tropospheric ozone sensitivity at UV wavelengths for deep convective clouds is largest within the upper portion of these clouds. To analyse the effect of the ozone absorption within deep convective clouds on the accuracy of the GOME-2/CCD method, the ozone column above highly reflective clouds $\left(a_{\mathrm{c}} \geq 0.75\right)$ over the eastern Indian Ocean and western Pacific has been determined as a function of cloud pressure (as provided by ROCINN). This makes it possible to use the ensemble cloud slicing technique to estimate ozone mixing ratios inside convective clouds (Ziemke et al., 2009a). Figure 4 shows four examples of the retrieved abovecloud ozone columns from GOME-2 measurements in October 2007 and March 2008. Here, the cloud pressure ranges from 175 to $700 \mathrm{hPa}$. However, the above-cloud column does not increase significantly for larger cloud top pressures. Using the ensemble cloud slicing technique, a small mean concentration of about 4-7 ppbv is found for the ozone inside the high reflective clouds in these regions of the tropical eastern Indian Ocean and western Pacific (corresponding to an ozone column of less than $1 \mathrm{DU}$ between the mean cloud top and the $200 \mathrm{hPa}$ level). Cloud slicing retrievals for other months show similar results: in general, very low (and even nearzero) ozone concentrations are found in the middle-to-upper 

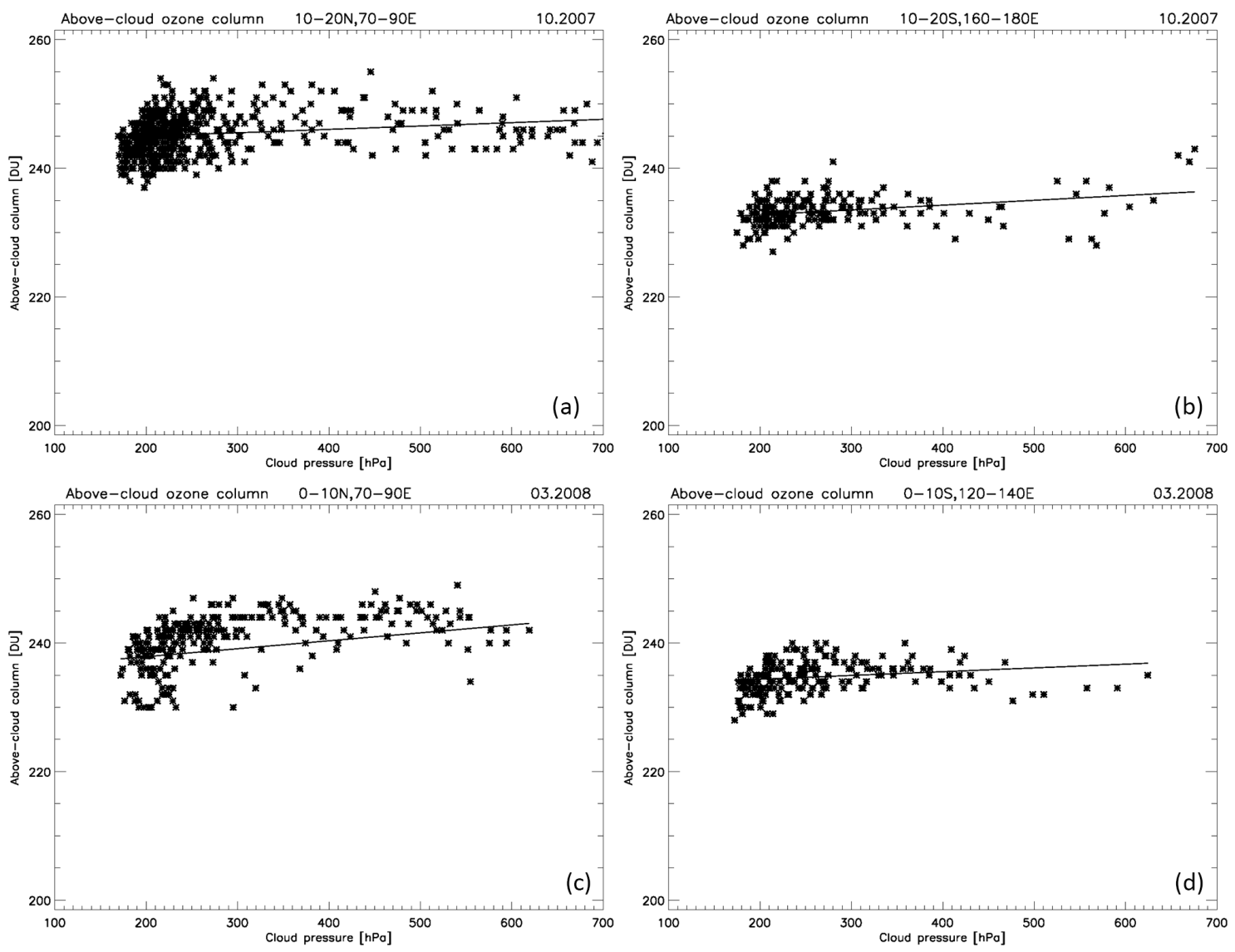

Figure 4. Scatter plot of the GOME-2 ozone column above highly reflective clouds (cloud albedo $\geq 0.75$ ) as a function of the GOME-2 cloudtop pressure (as provided by ROCINN) for 1-3 October 2007 (top) and 1-3 March 2008 (bottom). The regions are: 10-20 ${ }^{\circ} \mathrm{N} / 70-90^{\circ} \mathrm{E}$ (a), $10-20^{\circ} \mathrm{S} / 160-180^{\circ} \mathrm{E}(\mathbf{b}), 0-10^{\circ} \mathrm{N} / 70-90^{\circ} \mathrm{E}$ (c) and $0-10^{\circ} \mathrm{S} / 120-140^{\circ} \mathrm{E}$ (d). From the regression fittings, mean ozone concentrations of 4-7 ppbv are found in the middle-to-upper troposphere of these regions.

troposphere over much of this tropical region. These results are consistent with the OMI measurements from Ziemke et al. (2009a), and with lidar measurements in the tropical Pacific showing ozone concentrations of $7-10 \mathrm{ppbv}$ in convective air masses in the upper troposphere (Browell et al., 2001).

These analyses indicate that the GOME-2/CCD method will provide an accurate estimate of the tropical stratospheric column because the ozone mixing ratio inside deep convective clouds in the eastern Indian Ocean and western Pacific is exceedingly small.

\section{Tropical tropospheric ozone and $\mathrm{NO}_{2}$ distributions}

With the CCD method, monthly mean tropospheric ozone columns have been calculated on a $1.25^{\circ}$ latitude by $2.5^{\circ}$ longitude grid for the tropical region from January 2007 to December 2013, using GOME-2 data from both MetOp-A and MetOp-B. The GOME-2 tropical TOC can be used in combination with GOME-2 tropospheric $\mathrm{NO}_{2}$ measurements to analyse the tropospheric ozone distribution in the tropics, as illustrated in the following examples.

Figure 5 shows the tropical $\mathrm{NO}_{2}$ and tropospheric ozone columns for October 2013, as derived from GOME-2 data of MetOp-A and MetOp-B. This figure illustrates the effect of lightning and soil $\mathrm{NO}_{\mathrm{x}}$ sources, biomass burnings as well as dynamical processes on the tropical tropospheric ozone and $\mathrm{NO}_{2}$ distribution. During the southern biomass burning season in August-October, fires produced large amounts of $\mathrm{NO}_{2}$ over southern Africa and South America as can be seen in the top panel. Also visible are the $\mathrm{NO}_{\mathrm{x}}$ emissions over densely populated areas and mega cities, such as Mexico City, Jakarta and Bangkok. (Note that the contribution of lightning $\mathrm{NO}_{\mathrm{x}}$ emissions to the tropospheric $\mathrm{NO}_{2}$ column shown in Fig. 5 is limited since only GOME-2 measurements with small cloud fractions have been used (see Sect. 3.2), and because of the unbalanced partitioning of lightning $\mathrm{NO}_{\mathrm{x}}$ between $\mathrm{NO}$ and $\mathrm{NO}_{2}$ in the upper troposphere at the GOME-2 overpass time). The right panel of Fig. 5 shows that large tropospheric ozone columns are found over the southern Atlantic and southern Africa, while low tropospheric ozone concentrations are 

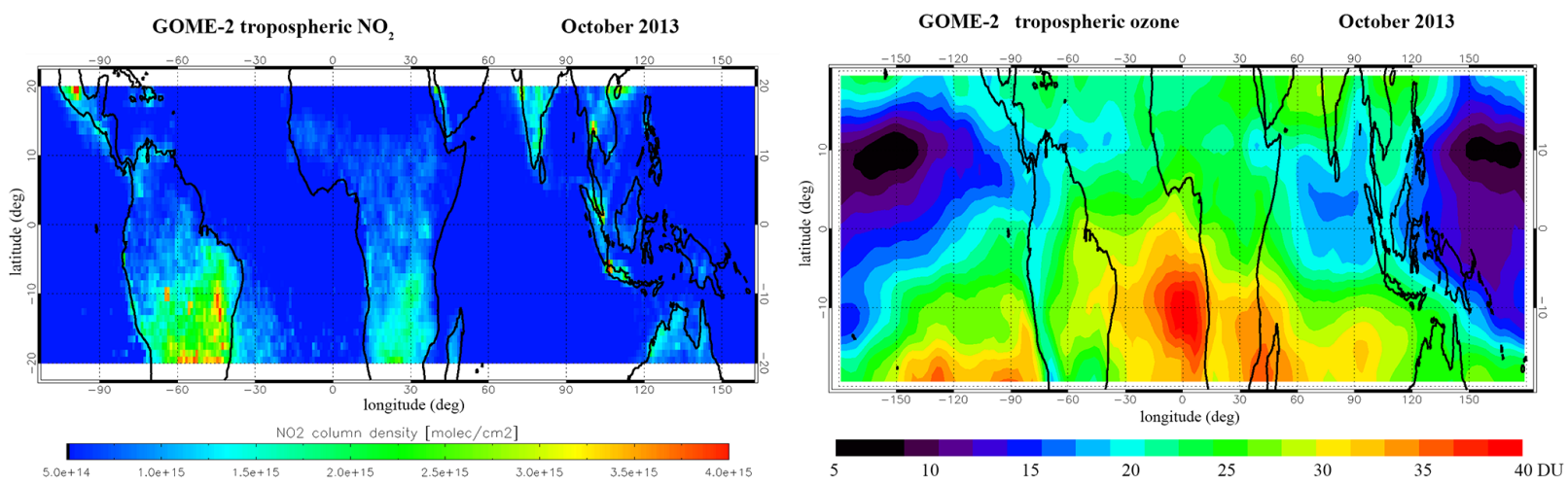

Figure 5. Tropospheric $\mathrm{NO}_{2}$ (left) and ozone columns (right) for October 2013, as retrieved from GOME-2 data of both MetOp-A and MetOp-B.

found over the tropical Pacific. The enhanced tropospheric ozone over the southern tropical Atlantic is mainly a result of dynamical processes, with permanent radiative subsidence over the quasi-stationary South Atlantic anticyclone area, allowing ozone production during downward transport. The Atlantic ozone maximum in September-November can be explained by a combination of lightning and soil $\mathrm{NO}_{\mathrm{x}}$ sources, a maximum intensity of fires over Africa and South America, as well as a maximum in long-range transport (Sauvage et al., 2007; Martin et al., 2007; Ziemke et al., 2009b). The low ozone values over the tropical Pacific can largely be attributed to convective lifting of low amounts of ozone clean air from the lower troposphere (including the pollution-free marine boundary) into the middle and upper troposphere (e.g. Solomon et al., 2005). Here, GOME-2 measures minimum tropospheric ozone columns of $\sim 10 \mathrm{DU}$. These low ozone values are consistent with ozonesonde measurements in the West Pacific, showing ozone concentrations of $\sim 15 \mathrm{ppbv}$ and lower in the tropical troposphere (Kley et al., 1996; Rex et al., 2014). Lidar measurements carried out during the PEM-Tropics B campaign also show very low ozone in the marine boundary layer and upper troposphere in the Pacific (Browell et al., 2001).

The ENSO causes significant perturbations to both the oceanic and atmospheric circulations. These changes in circulation impact the temperature and moisture fields over the tropical Pacific and have a significant impact on the chemical composition of the troposphere (Chandra et al., 2009; Lee et al., 2010). The 2009-2010 ENSO influences on the large-scale circulation and the variations in biomass burning emissions resulted in distinct differences between the tropospheric $\mathrm{NO}_{2}$ and ozone distributions in the tropics, as illustrated in Fig. 6. The top panels show the tropospheric $\mathrm{NO}_{2}$ and ozone distributions as measured by GOME2/MetOp-A for October 2009. El Niño induced dry conditions resulted in an increase in biomass burnings in Northern Australia and Indonesia in September-October 2009, while biomass burning decreased in South America. This is clearly visible, for example, in the monthly global fire maps from the ATSR (Along-Trace Scanning Radiometer) satellite instrument (Arino et al., 2012). Figure 6 shows that the increase in the emissions of $\mathrm{NO}_{\mathrm{x}}$ and other ozone precursors resulted in enhanced $\mathrm{NO}_{2}$ over northern Australia, and in relatively high tropospheric ozone columns over the southern tropical Indian Ocean and northern Australia, while the tropospheric ozone columns over the western part of South America are relatively small. The El Niño induced dynamical changes also result in enhanced ozone in the Indian Ocean and western Pacific, and reduced ozone in the eastern Pacific (Chandra et al., 2009; Ziemke et al., 2010). The bottom panels of Fig. 6 show the GOME-2 tropospheric $\mathrm{NO}_{2}$ and ozone distributions for September 2010. The La Niña conditions in SeptemberOctober 2010 resulted in an increase of biomass burnings in South America and a reduction in fires in Indonesia and northern Australia. As can be seen in Fig. 6, the La Niña induced changes in biomass burnings and dynamics resulted in a strong increase in tropospheric $\mathrm{NO}_{2}$ in South America, and enhanced ozone over the eastern Pacific and South America, and reduced ozone over the western Pacific and Indian Ocean.

\section{Comparisons with ozonesonde measurements}

The accuracy of the CCD method has been assessed by comparing the GOME-2 TOC for the period 2007-2012 with tropical ozonesonde measurements from the SHADOZ network (Version 5), see Thompson et al. (2003a) and http: //croc.gsfc.nasa.gov/shadoz. Measurements have been used from eight sites: American Samoa $\left(14^{\circ} \mathrm{S}, 171^{\circ} \mathrm{W}\right)$, Hilo $\left(20^{\circ} \mathrm{N}, 155^{\circ} \mathrm{W}\right)$, Watukosek $\left(8^{\circ} \mathrm{S}, 113^{\circ} \mathrm{E}\right)$, Kuala Lumpur $\left(3^{\circ} \mathrm{N}, 102^{\circ} \mathrm{E}\right)$, Nairobi $\left(1^{\circ} \mathrm{S}, 37^{\circ} \mathrm{E}\right)$ and La Réunion $\left(21^{\circ} \mathrm{S}\right.$, $\left.55^{\circ} \mathrm{E}\right)$ in the tropical Pacific and Indian Ocean region, and Natal $\left(5^{\circ} \mathrm{S}, 35^{\circ} \mathrm{W}\right)$ and Ascension $\left(8^{\circ} \mathrm{S}, 14^{\circ} \mathrm{W}\right)$ in the tropical Atlantic region. For most sites, ozonesonde measurements are available throughout the period January 2007December 2012. For Ascension Island, Natal and Kuala 

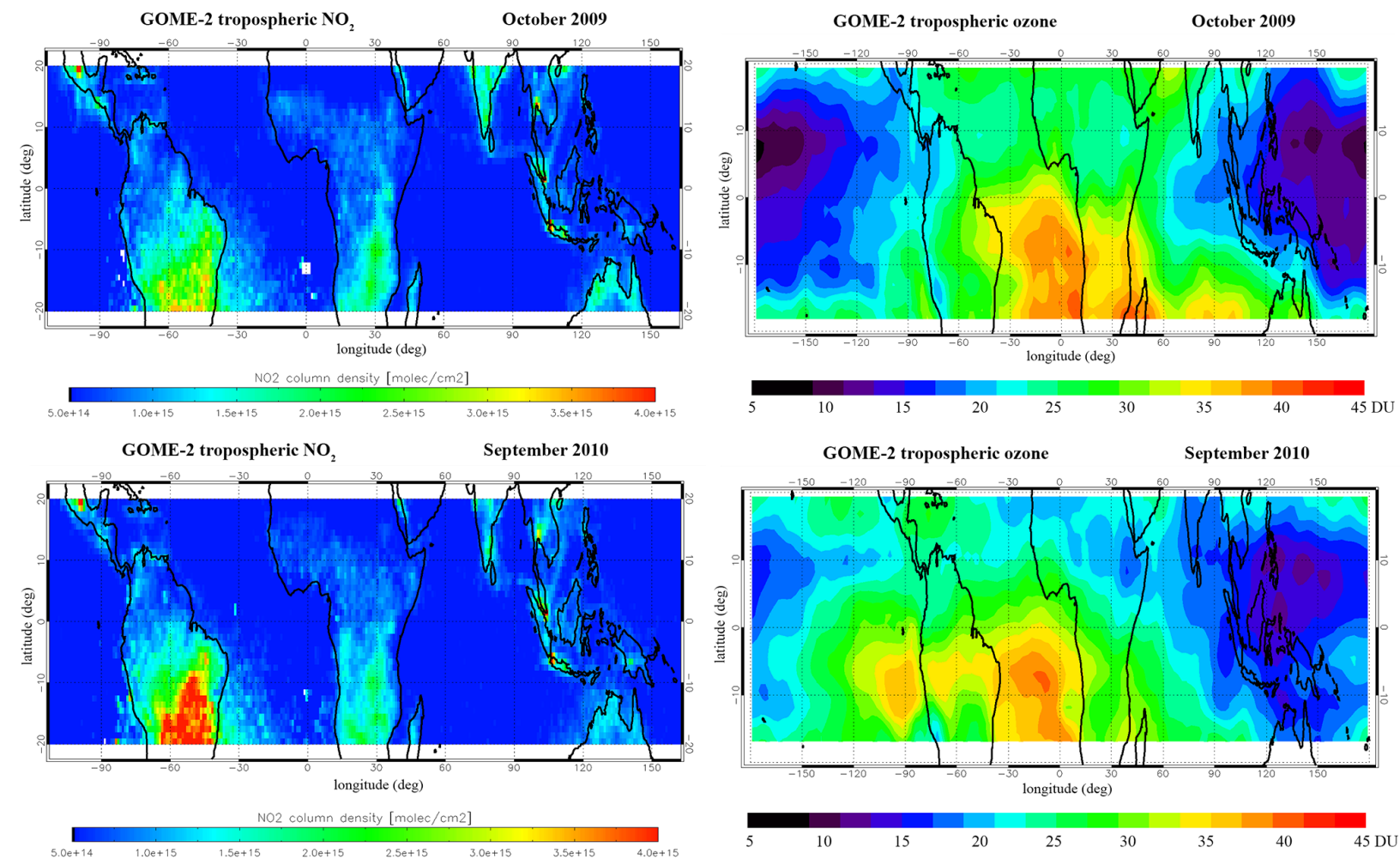

Figure 6. Tropospheric $\mathrm{NO}_{2}$ (left) and ozone columns (right) as measured by GOME-2/MetOp-A in October 2009 (top) and September 2010 (bottom).

Lumpur, sonde data are only available until July 2010, May 2011 and December 2011, respectively. For the comparison, the ozonesonde profiles have been integrated from the ground to the $200 \mathrm{hPa}$ pressure level and then the monthly ensemble averages and standard deviation were calculated. At most stations, there were between 2 to 5 ozonesonde measurements each month.

Figure $7 \mathrm{a}$ and $\mathrm{b}$ show the comparisons for the Brazilian station Natal and for Ascension Island. There is good agreement between the GOME-2 TOC and the sonde measurements at the two Atlantic sites, with an rms difference of only $3-4$ DU $(R=\sim 0.9)$. There is a strong yearly increase in tropospheric ozone during the biomass burning season, starting in June/July and ending in October/November. The comparison for the Nairobi station in Kenya is shown in Fig. 7c. At this equatorial eastern African site, tropospheric ozone also increases during the biomass burning season, but the maximum ozone column values are smaller than at the Natal and Ascension Island sites in the southern tropical Atlantic. The comparison for American Samoa is shown in Fig. 7d. Above Samoa over the Pacific Ocean, the tropospheric ozone columns are usually low, with values of less than $20 \mathrm{DU}$, due to deep convection of ozone-poor air. The smallest ozone values of $\sim 10 \mathrm{DU}$ are found around February. In this period, individual ozone profiles at Samoa show very low ozone concentrations ( $\sim 15 \mathrm{ppbv}$ and lower). The small increase in the
TOC between August and November is ozone-rich air transported from South East Asia and African biomass burning areas (Sauvage et al., 2007; Thompson et al., 2003b) and is captured by GOME-2 as well. The GOME-2/CCD method seems to slightly underestimate the sonde data at the three sites, but is most of the time within the $1 \sigma$ uncertainty.

Table 1 lists the average GOME-2 and ozonesonde TOC at the eight SHADOZ locations, the bias and rms difference between GOME-2 and the sondes, and the correlation coefficient $R$. For all sites, the bias is within $\sim 3 \mathrm{DU}$ and the rms difference between 3 and 5 DU. The larger bias and rms numbers at La Réunion can largely be explained by its southern location under the influence of sub-tropical air, and the sparse nature of monthly GOME-2 TOC measurements.

It should be noted that the temporal and geographical variability of the tropospheric ozone column is large and there is usually only one sonde measurement each week. The uncertainty in the monthly averaged TOC from sondes can therefore be quite large, as can be seen from the occasionally large $1 \sigma$ intervals in Fig. 7. A further complication for the interpretation of the TOC with ozonesondes is the fact that GOME-2 provides an average value over a relatively large region, while the ozonesondes represent wind-advected measurements along trajectory paths. Therefore, the satellite versus ozonesonde comparisons are more useful to evaluate seasonal cycles and climatological means, and large 

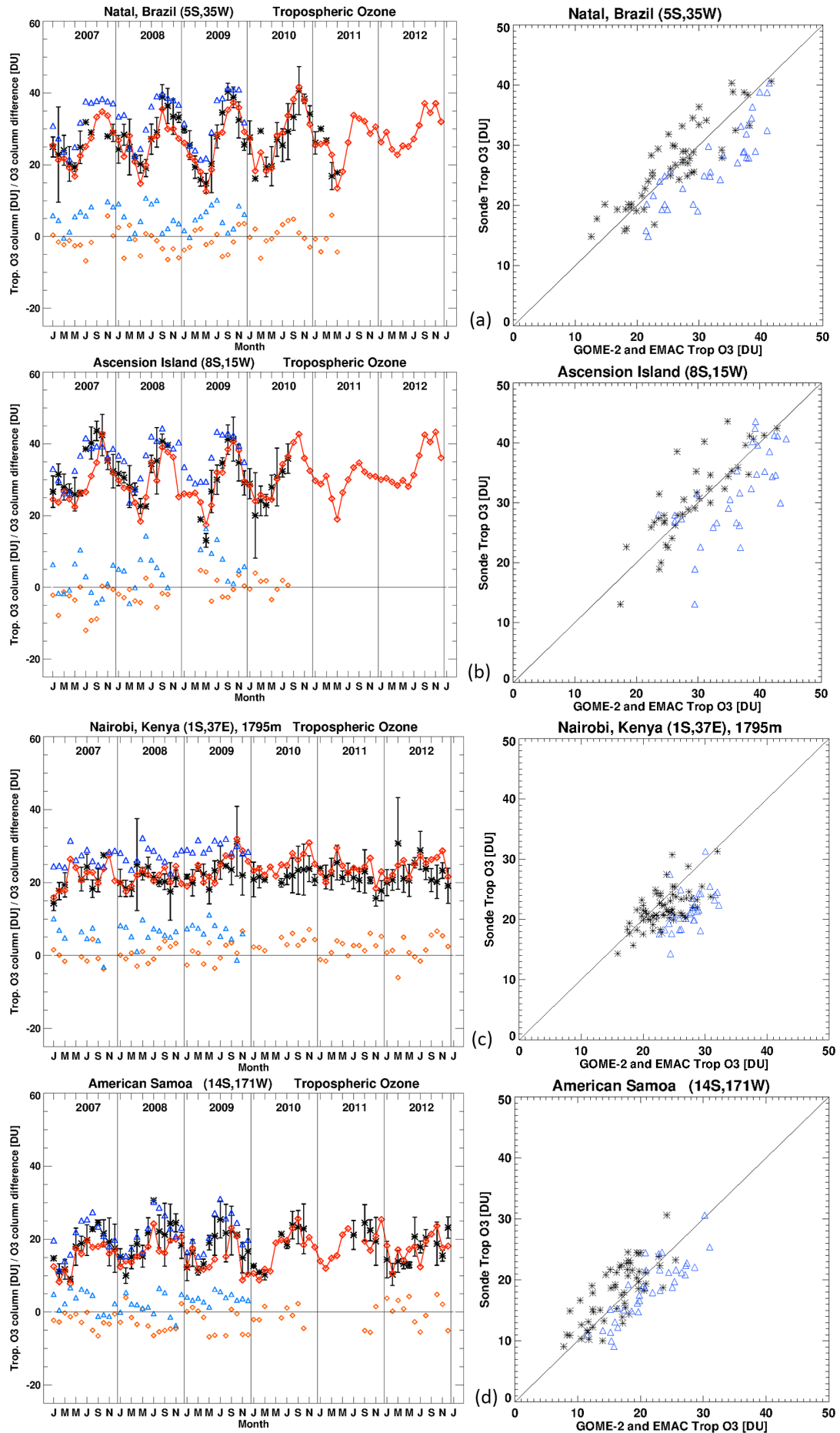

Figure 7. Tropospheric ozone columns for (a) Natal $\left(5^{\circ} \mathrm{S}, 35^{\circ} \mathrm{W}\right)$, (b) Ascension $\left(8^{\circ} \mathrm{S}, 14^{\circ} \mathrm{W}\right)$, (c) Nairobi $\left(1^{\circ} \mathrm{S}, 37^{\circ} \mathrm{E}\right)$ and $(\mathbf{d})$ American Samoa $\left(14^{\circ} \mathrm{S}, 171^{\circ} \mathrm{W}\right)$ for the period January $2007-$ December 2012 . The asterisks denote the integrated ozonesonde measurements (monthly ensemble average) with $1 \sigma$ error bars. The number of individual ozonesonde profiles at the four sites varies between 1 to 5 per month (if there is only one sonde measurement in a particular month, the error bar is omitted). The red diamonds denote the tropospheric ozone columns derived with the GOME-2/CCD method; the blue triangles are tropospheric ozone columns from the EMAC model (see Sect. 7). The small diamonds and triangles show the difference in the ozone columns (GOME-2 - ozonesonde and EMAC - ozonesonde, respectively). Scatter plots of ozonesonde versus GOME-2 (black) and EMAC (blue) monthly mean TOCs for the three sites are shown on the right. 
Table 1. Statistical comparison between GOME-2 and ozonesonde TOCs based on monthly ensemble averages for eight SHADOZ sites. Included for each site are the measurement period, the mean TOC from GOME-2 and the ozonesondes, the bias and rms difference between the two, and the correlation coefficient $R$. The ozone column values are in DU.

\begin{tabular}{lcccccc}
\hline Ozonesonde site & Period & GOME-2 & Sonde & Bias & Diff rms & $R$ \\
\hline Samoa $\left(14^{\circ} \mathrm{S}, 171^{\circ} \mathrm{W}\right)$ & $01.07-12.12$ & 16.3 & 18.0 & -1.7 & 3.6 & 0.75 \\
Hilo $\left(20^{\circ} \mathrm{N}, 155^{\circ} \mathrm{W}\right)$ & $01.07-12.12$ & 28.2 & 26.1 & +2.1 & 4.7 & 0.81 \\
Natal $\left(5^{\circ} \mathrm{S}, 35^{\circ} \mathrm{W}\right)$ & $01.07-05.11$ & 26.0 & 26.9 & -0.9 & 3.4 & 0.89 \\
Ascension Isl. $\left(8^{\circ} \mathrm{S}, 14^{\circ} \mathrm{W}\right)$ & $01.07-07.10$ & 29.4 & 30.8 & -1.4 & 3.9 & 0.85 \\
Nairobi $\left(1^{\circ} \mathrm{S}, 37^{\circ} \mathrm{E}\right)$ & $01.07-12.12$ & 23.4 & 21.8 & +1.6 & 3.3 & 0.61 \\
La Réunion $\left(21^{\circ} \mathrm{S}, 55^{\circ} \mathrm{E}\right)$ & $07.07-12.12$ & 24.4 & 28.7 & -4.3 & 6.2 & 0.73 \\
Kuala Lumpur $\left(3^{\circ} \mathrm{N}, 102^{\circ} \mathrm{E}\right)$ & $01.07-04.10$ & 17.1 & 18.9 & -1.8 & 3.2 & 0.32 \\
Watukosek $\left(8^{\circ} \mathrm{S}, 113^{\circ} \mathrm{E}\right)$ & $01.07-12.12$ & 17.1 & 20.8 & -3.7 & 5.6 & 0.54 \\
\hline
\end{tabular}

variability such as inter-annual changes in the TOC induced by ENSO.

\section{Comparisons with chemistry-climate simulations}

An important application of satellite tropospheric ozone data is the evaluation of CCMs (e.g. Oman et al., 2013; Loyola et al., 2009). CCMs are numerical tools which are used to study connections between atmospheric chemistry and climate. They are composed of two basic parts: an atmospheric general circulation model (AGCM) and a chemistry model which are interactively coupled. The simulated concentrations of the radiatively active gases are used in the calculations of heating and cooling rates. Changes in the abundance of these gases due to chemistry and advection influence heating and cooling rates and, consequently, variables describing atmospheric dynamics such as temperature and wind. CCMs are important tools for the assessment of the past, present and future of changes of climate and chemical composition. The validation of atmospheric model systems with observed data regarding their possibilities to describe atmospheric changes is necessary, providing a foundation for prognostic studies.

Since the spatial scales of the satellite and model ozone fields are comparable, we analyse the usefulness of tropical TOC data derived with the CCD method in evaluating CCMs. Here, we compare the GOME-2 tropospheric ozone data with simulations of the ECHAM/MESSy Atmospheric Chemistry (EMAC) model, and analyse the variability in the TOC and the ozone response to $2009 \mathrm{El}$ Niño conditions.

\subsection{EMAC model}

EMAC is a numerical chemistry and climate simulation system that includes sub-models describing tropospheric and middle atmosphere processes and their interaction with oceans, land and human influences (Jöckel et al., 2010). It uses the second version of the Modular Earth Submodel System (MESSy2) to link multi-institutional computer codes. The core atmospheric model is the fifth generation European Centre Hamburg general circulation model (ECHAM5,
Roeckner et al., 2006). For the present study we applied EMAC (ECHAM5 version 5.3.02, MESSy version 2.41) in the T42L90MA-resolution, i.e. with a spherical truncation of T42 (corresponding to a quadratic Gaussian grid of approx. 2.8 by 2.8 degrees in latitude and longitude) with 90 vertical hybrid pressure levels up to $0.01 \mathrm{hPa}$. The simulation spans the years 1998 to 2009, the model dynamics (vorticity, divergence, temperature and logarithm of surface pressure) was nudged by Newtonian relaxation towards operational analysis data from ECMWF. This technique allows the direct comparison of model results with observations, since the observed (resp. assimilated) synoptic scale meteorology is reproduced by the model (Jöckel et al., 2006). The gas phase chemistry is calculated by the submodel MECCA (Sander et al., 2011) with a comprehensive stratospheric and tropospheric chemistry mechanism including NMHC chemistry (up to $\mathrm{C} 4$ plus isoprene). Aqueous phase chemistry and wet-scavenging are simulated by the submodel SCAV (Tost et al., 2006), dry deposition by the submodel DRYDEP (Kerkweg et al., 2006a), primary emissions by the submodels ONLEM, OFFLEM and TNUDGE (Kerkweg et al., 2006b). Monthly anthropogenic emissions representative for the year 2000 have been used for all simulated years from Lamarque et al. (2010). Monthly biomass burning emissions for the years 1998 to 2009 have been taken from the Global Fire Emission Database (GFED v3.1; Van der Werf et al., 2010). For this study, we used monthly average tropospheric ozone columns calculated from 5-hourly model output.

\subsection{Tropospheric ozone variations}

In Fig. 7 also the respective results of EMAC are displayed for the four stations Natal, Ascension Island, Nairobi, and American Samoa. Despite an offset towards higher tropospheric ozone columns (mean biases of 3-6 DU), the model describes well seasonal cycles and the inter-annual fluctuations in accordance with observations. The generally high bias of the EMAC simulations (especially at Natal and Ascension Island) is most likely related to biased emissions of ozone precursors and deficiencies in tracer transport. 

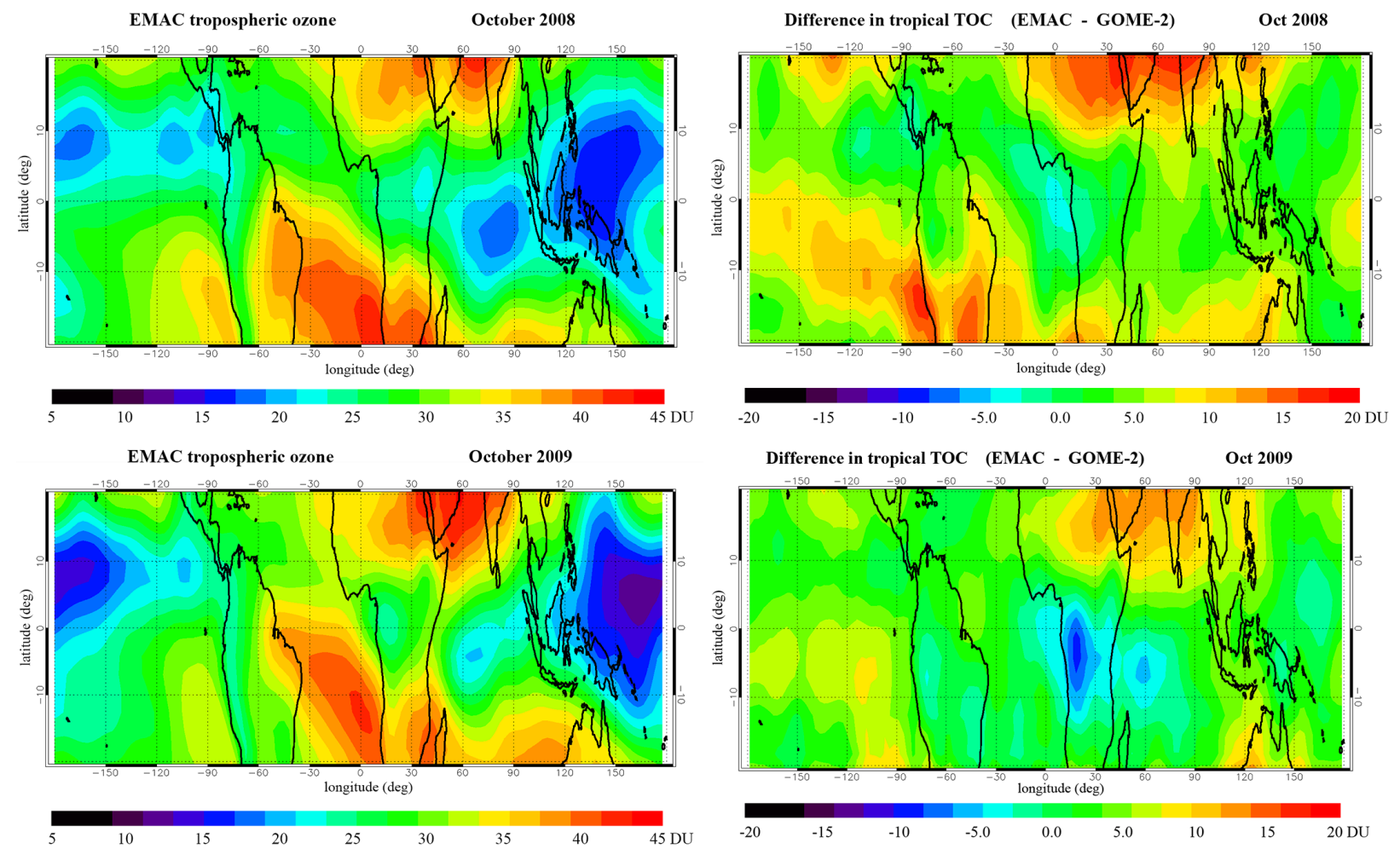

Figure 8. Tropospheric ozone columns calculated with the EMAC model (left) and the difference in the tropospheric ozone columns from EMAC and GOME-2 (right). The maps are for October 2008 (top) and 2009 (bottom).

Deficiencies in emission data sets are known to give the largest uncertainty in CCM simulations (e.g. Pozzer et al., 2007). It is likely that the deviation over Natal and Ascension Island is a systematic, combined effect of the timing of the precursor emissions (mainly biomass burning activity in South America and Africa) and transport. Despite the nudging of the EMAC simulations towards ECMWF operational analysis data, smaller-scale transport, in particular by convection, could under- or overestimate the vertical redistribution of emitted ozone precursors, which will alter their lifetimes and therefore also their long-range transport.

For comparison with the GOME-2 tropical TOC distributions for October (Figs. 5 and 6), simulation results derived from EMAC are presented in Fig. 8 for October 2008 and 2009, together with the corresponding EMAC-GOME-2 difference maps. Generally, there is good agreement of the spatial patterns of high and low ozone values. In particular, in the southern tropical region, high tropical ozone is reproduced by EMAC in the eastern Atlantic, east Southern Africa, and over the Pacific, west of Australia. Pronounced low ozone values are found the inner tropics in the Western Pacific. EMAC simulates high tropospheric ozone columns in the northern tropics in the region of the Near East and India which are not present in the GOME-2 data. The EMAC vs. GOME-2 difference maps also reveal a negative bias in EMAC for west tropical Africa. This EMAC tropical ozone "minimum" could be explained by an underestimation of precursor emissions (from biomass burning and lightning), since the tropospheric ozone column in this area is very sensitive to changes in precursor emissions (e.g. see Fig. 3 in Sauvage et al., 2007). In addition, dynamical processes could play a role as well (i.e. too strong convective uplift and subsequent large-scale transport). An upcoming exercise regarding this inconsistency between model and satellite observations is to study in more detail and clarify possible reasons - do we have problems/uncertainties with respect to the prescribed emissions/boundary conditions in EMAC, or are there indications for difficulties with the deduced values derived from the GOME-2 measurements here?

To evaluate the response of the 2009 El Niño conditions on the observed and simulated tropospheric ozone distribution, we calculated the difference between the GOME-2 tropical TOC in October 2009 and October 2008 (Fig. 9, left panel), as well as the simulated difference (lower panel). Both the GOME-2 and EMAC ozone difference maps show enhanced ozone in the Indian Ocean and western Pacific, and reduced ozone in the eastern Pacific, as a result of the El Niño induced dynamical changes in 2009. Although the basic difference pattern assessed from observed and model data are satisfactory in agreement, there are clear differences with respect to the absolute difference values between these two October episodes in 2008 and 2009. It gives some indications for 

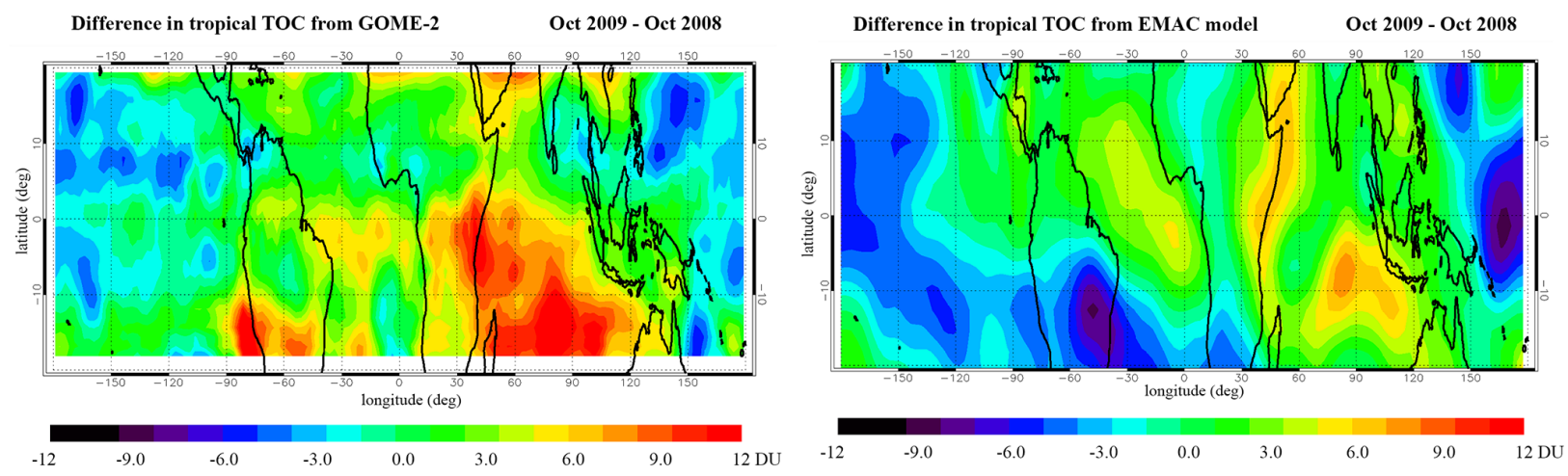

Figure 9. Difference between the tropical TOC in October 2009 and 2008: (left) difference in the TOC derived with the GOME-2/CCD method and (right) difference in the TOC calculated with the EMAC model.

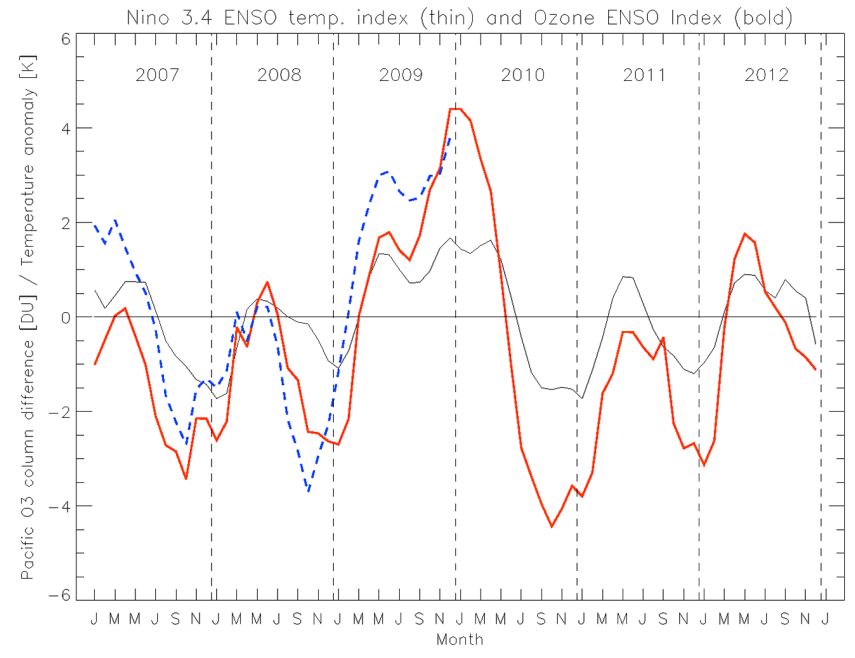

Figure 10. Time series of the Ozone ENSO index (bold lines) versus Niño 3.4 SST index (thin black line). The solid red line denotes the OEI derived from the GOME-2 TOC data, the dashed blue line shows the OEI derived from EMAC simulations.

EMAC problems regarding to reproduce particular events. Clarifying this problem will need further investigations with EMAC.

Ziemke et al. (2010) derived an Ozone ENSO index (OEI) to analyse the response of tropical tropospheric ozone to the perturbation in atmospheric dynamics that is due to the ENSO signature in tropical sea-surface temperature (SST). The OEI is obtained by averaging gridded TOC over two broad equal-area regions in the Indian Ocean/western Pacific $\left(15^{\circ} \mathrm{N}-15^{\circ} \mathrm{S}, 70^{\circ}-140^{\circ} \mathrm{E}\right)$ and eastern Pacific $\left(15^{\circ} \mathrm{N}-15^{\circ} \mathrm{S}\right.$, $110-180^{\circ} \mathrm{W}$ ), then taking their difference (western minus eastern Pacific TOC) and applying a 3-month running average. Figure 10 shows the OEI derived from the GOME-2 TOC data for the period 2007-2012, and from the EMAC model data for 2007-2009. The Niño 3.4 index based upon sea-surface temperature anomalies in the eastern Pacific is shown as well. There is good agreement between the GOME2 and EMAC OEI time series, and a high correlation with the Niño 3.4 index is found ( 0.90 for the GOME-2 OEI; 0.81 for the EMAC OEI). During El Niño, the positive phase of ENSO, the OEI anomaly is positive, corresponding to increased ozone over the western region and decreased ozone over the eastern region, while La Niña has the opposite effect. The positive response in the OEI during the $2009 \mathrm{El}$ Niño is $\sim 4$ DU. A similar negative anomaly is found during 2010 La Niña conditions. A linear regression reveals that a $+1.0 \mathrm{~K}$ change in Niño 3.4 index corresponds to $+2.0 \mathrm{DU}$ change in the OEI for both the observed and simulated data. Similar results were obtained by Oman et al. $(2011,2013)$ using OMI, MLS and TES satellite measurements, and GEOS CCM simulations.

These analyses demonstrate the clear ozone response to ENSO observed in GOME-2 TOC measurements, which can be reproduced in the EMAC model simulations. This requires both a realistic response of the circulation to the SST and realistic simulated horizontal and vertical ozone gradients.

\section{Summary and conclusions}

In this paper, we have described the retrieval of tropical tropospheric ozone columns (TOC) from GOME-2 measurements using the convective-cloud-differential (CCD) method. The GOME-2/CCD method is based on cloud and total ozone measurements provided by the GOME Data Processor (GDP) 4.7. The cloud parameters (cloud fraction, cloud pressure and albedo) derived with the OCRA/ROCINN algorithms indicate that the effective cloud pressure level of most tropical convective clouds is between 200 and $400 \mathrm{hPa}$. Cloud slicing analyses using GOME-2 total ozone and cloud data show that generally very low ozone amounts are found inside the high reflective tropical clouds in the eastern Indian Ocean and western Pacific. This is an important prerequisite for the CCD method, which uses above-cloud and clearsky ozone column measurements to derive the monthly mean 
tropospheric TOC. Comparisons with ozonesonde measurements from the SHADOZ network show that the assumption of the GOME-2/CCD method of a zonally invariant stratospheric ozone column has good validity in the tropics. An important advantage of the CCD method is that it is insensitive to the GOME-2 instrument degradation.

Monthly mean TOC have been calculated on a $1.25^{\circ}$ latitude by $2.5^{\circ}$ longitude grid (between $20^{\circ} \mathrm{N}$ and $20^{\circ} \mathrm{S}$ ) for January 2007 to December 2013, using GOME-2 data from both MetOp-A and MetOp-B. The tropical TOC data have been used in combination with GOME-2 tropospheric $\mathrm{NO}_{2}$ measurements to analyse the variability in the tropospheric ozone in the tropics. The 2009-2010 ENSO influences on the large-scale circulation and biomass burnings had a significant impact on the tropospheric $\mathrm{NO}_{2}$ and ozone distribution. El Niño induced dry conditions in September-October 2009 resulted in relatively high tropospheric ozone columns over the southern Indian Ocean and northern Australia, while La Niña conditions in September-October 2010 resulted in a strong increase in tropospheric $\mathrm{NO}_{2}$ in South America, and enhanced ozone in the eastern Pacific and South America.

Validation of the GOME-2 tropical TOC with six SHADOZ ozonesonde sites in the tropical Pacific and Indian Ocean and two ozonesonde sites in the tropical Atlantic show good agreement, with a high correlation between the GOME2 and sonde measurements. The bias is generally within 3 DU and the rms differences between 3 and 5 DU.

The first use of the GOME-2 tropical TOC comparing it with respective simulation results derived from the CCM EMAC is impressive, indicating the potential for further investigations. It will help not only to identify model uncertainties, but it will improve our knowledge of atmospheric short- and long-term variability including the identification of trends. It indicates that this data set provides a significant contribution and substantial input for research projects, like the current EC StratoClim FP7 project (Stratospheric and upper tropospheric processes for better climate predictions) to investigate chemistry-climate connections. Such comprehensive data sets and related investigations provide an important contribution for international assessment reports, for instance the UNEP/WMO Scientific Assessment of Ozone Depletion: 2014 (in preparation; to be published in WMO, 2015) and the Climate Assessment Report of IPCC (5AR of IPCC, 2013). Moreover, it provides significant input for climate services and an important contribution to monitor the Earth atmosphere (UNEP-WCMC program).

The GOME-2 tropical TOC product has been developed in the framework of EUMETSAT's Satellite Application Facility on Ozone and Atmospheric Chemistry Monitoring (O3M$\mathrm{SAF}$, and is generated at the O3M-SAF processing facility in DLR. GOME-2 TOC product will be available via the GOME portal at DLR (http://atmos.caf.dlr.de/gome2). GOME-2 products can also be ordered at the Help Desk of the O3M-SAF hosted by the Finnish Meteorological Institute (FMI) (o3msaf@fmi.fi). The GOME-2 Algorithm
Theoretical Basis Document (ATBD), Product User Manual (PUM), Validation Reports, as well as quick-look images and links to related services are available at the DLR-GOME portal (http://atmos.caf.dlr.de/gome2).

The tropical TOC data set based on the CCD method will be extended with the GOME/ERS-2 and SCIAMACHY/ENVISAT time period in the framework of the ESA CCI programme phase II. In the same way, the CCD method will be applied to the next generation of European atmospheric composition missions staring with the TROPOMI sensor on-board the Sentinel 5 Precursor satellite to be launched in 2015.

Acknowledgements. Development of the GOME-2 tropospheric ozone column products and their validation has been funded by the O3M-SAF project with EUMETSAT and national contributions. We thank EUMETSAT for the ground-segment interfacing work with the O3M-SAF systems and for the provision of GOME-2 level-1 products.

The service charges for this open access publication have been covered by a Research Centre of the Helmholtz Association.

Edited by: R. Munro

\section{References}

Antón, M. and Loyola, D.: Influence of cloud properties on satellite total ozone observations, J. Geophys. Res., 116, D03208, doi:10.1029/2010JD014780, 2011.

Arino, O., Casadio, S., and Serpe, D.: Global night-time fire season timing and fire count trends using the ATSR instrument series, Remote Sens. Environ., 116, 226-238, doi:10.1016/j.rse.2011.05.025, 2012.

Bovensmann, H., Burrows, J. P., Buchwitz, M., Frerick, J., Rozanov, V. V., Chance, K. V., and Goede, A. P. H.: SCIAMACHY: Mission objectives and measurement modes, J. Atmos. Sci., 56, 127-150, doi:10.1175/15200469(1999)056<0127:SMOAMM>2.0.CO;2, 1999.

Brion, J., Chakir, A., Charbonnier, J., Daumont, D., Parisse, C., and Malicet, J.: Absorption spectra measurements for the ozone molecule in the 350-830 nm region, J. Atmos. Chem., 30, 291299, 1998.

Browell, E. V., Fenn, M. A., Butler, C. F., Grant, W. B., Ismail, S., Ferrare, R. A., Kooi, S. A., Brackett, V. G., Clayton, M. B., Avery, M. A., Barrick, J. D. W., Fuelberg, H. E., Maloney, J. C., Newell, R. E., Zhu, Y., Mahoney, M. J., Anderson, B. E., Blake, D. R., Brune, W. H., Heikes, B. G., Sachse, G. W., Singh, H. B., and Talbot, R. W.: Large-scale air mass characteristics observed over the remote tropical Pacific Ocean during March-April 1999: Results from PEM-Tropics B field experiment, J. Geophys. Res., 106, 32481-32501, 2001.

Burrows, J., Weber, M., Buchwitz, M., Rozanov, V., LadstätterWeißenmayer, A., Richter, A., Debeek, R., Hoogen, R., Bramstedt, K., Eichmann, K.-U., and Eisinger, M.: The Global Ozone 
Monitoring Experiment (GOME): Mission concept and first scientific results, J. Atmos. Sci., 56, 151-175, 1999.

Callies, J., Corpaccioli, E., Eisinger, M., Hahne, A., and Lefebvre, A.: GOME-2 - MetOp's Second Generation Sensor for Operational Ozone Monitoring, ESA Bull.-Eur. Space, 102, 28-36, 2000.

Chandra, S., Ziemke, J. R., Duncan, B. N., Diehl, T. L., Livesey, N. J., and Froidevaux, L.: Effects of the 2006 El Niño on tropospheric ozone and carbon monoxide: implications for dynamics and biomass burning, Atmos. Chem. Phys., 9, 4239-4249, doi:10.5194/acp-9-4239-2009, 2009.

Clerbaux, C., Boynard, A., Clarisse, L., George, M., Hadji-Lazaro, J., Herbin, H., Hurtmans, D., Pommier, M., Razavi, A., Turquety, S., Wespes, C., and Coheur, P.-F.: Monitoring of atmospheric composition using the thermal infrared IASI/MetOp sounder, Atmos. Chem. Phys., 9, 6041-6054, doi:10.5194/acp-9-6041-2009, 2009.

Cuesta, J., Eremenko, M., Liu, X., Dufour, G., Cai, Z., Höpfner, M., von Clarmann, T., Sellitto, P., Foret, G., Gaubert, B., Beekmann, M., Orphal, J., Chance, K., Spurr, R., and Flaud, J.-M.: Satellite observation of lowermost tropospheric ozone by multispectral synergism of IASI thermal infrared and GOME-2 ultraviolet measurements over Europe, Atmos. Chem. Phys., 13, 9675-9693, doi:10.5194/acp-13-9675-2013, 2013.

Ebojie, F., von Savigny, C., Ladstätter-Weißenmayer, A., Rozanov, A., Weber, M., Eichmann, K.-U., Bötel, S., Rahpoe, N., Bovensmann, H., and Burrows, J. P.: Tropospheric column amount of ozone retrieved from SCIAMACHY limb-nadir-matching observations, Atmos. Meas. Tech., 7, 2073-2096, doi:10.5194/amt-72073-2014, 2014.

Folkins, I., Loewenstein, M., Podolske, J., Oltmans, S., and Proffitt, M.: A barrier to vertical mixing at $14 \mathrm{~km}$ in the tropics: Evidence from ozonesondes and aircraft measurements, J. Geophys. Res., 104, 22095-22101, 1999.

Foster, P. M. and Shine, K. P.: Radiative forcing and temperature trends from stratospheric ozone changes, J. Geophys. Res., 102, 10841-10856, 1997.

Fueglistaler, S., Dessler, A. E., Dunkerton, T. J., Folkins, I., Fu, Q., and Mote, P. W.: Tropical tropopause layer, Rev. Geophys., 47, RG1004, doi:10.1029/2008RG000267, 2009.

Hao, N., Koukouli, M. E., Inness, A., Valks, P., Loyola, D. G., Zimmer, W., Balis, D. S., Zyrichidou, I., Van Roozendael, M., Lerot, C., and Spurr, R. J. D.: GOME-2 total ozone columns from MetOp-A/MetOp-B and assimilation in the MACC system, Atmos. Meas. Tech. Discuss., 7, 2259-2299, doi:10.5194/amtd-72259-2014, 2014.

Heinen, T., Kiemle, S., Buckl, B., Mikusch, E., and Loyola, D.: The Geospatial Service Infrastructure for DLR's National Remote Sensing Data Library, IEEE J. Select. Topics Appl. Earth Obs. Rem. Sens., 2, 260-269, 2009.

IPCC: Climate Change 2013: The Physical Science Basis. Contribution of Working Group I to the Fifth Assessment Report of the Intergovernmental Panel on Climate Change, edited by: Stocker, T. F., Qin, D., Plattner, G.-K., Tignor, M., Allen, S. K., Boschung, J., Nauels, A., Xia, Y., Bex, V., and Midgley, P. M., Cambridge University Press, Cambridge, United Kingdom and New York, NY, USA, 1535 pp., 2013.

Jöckel, P., Tost, H., Pozzer, A., Brühl, C., Buchholz, J., Ganzeveld, L., Hoor, P., Kerkweg, A., Lawrence, M. G., Sander, R., Steil,
B., Stiller, G., Tanarhte, M., Taraborrelli, D., van Aardenne, J., and Lelieveld, J.: The atmospheric chemistry general circulation model ECHAM5/MESSy1: consistent simulation of ozone from the surface to the mesosphere, Atmos. Chem. Phys., 6, 50675104, doi:10.5194/acp-6-5067-2006, 2006.

Jöckel, P., Kerkweg, A., Pozzer, A., Sander, R., Tost, H., Riede, H., Baumgaertner, A., Gromov, S., and Kern, B.: Development cycle 2 of the Modular Earth Submodel System (MESSy2), Geosci. Model Dev., 3, 717-752, doi:10.5194/gmd-3-717-2010, 2010.

Joiner, J., Vasilkov, A. P., Gupta, P., Bhartia, P. K., Veefkind, P., Sneep, M., de Haan, J., Polonsky, I., and Spurr, R.: Fast simulators for satellite cloud optical centroid pressure retrievals; evaluation of OMI cloud retrievals, Atmos. Meas. Tech., 5, 529-545, doi:10.5194/amt-5-529-2012, 2012.

Kerkweg, A., Buchholz, J., Ganzeveld, L., Pozzer, A., Tost, H., and Jöckel, P.: Technical Note: An implementation of the dry removal processes DRY DEPosition and SEDImentation in the Modular Earth Submodel System (MESSy), Atmos. Chem. Phys., 6, 4617-4632, doi:10.5194/acp-6-4617-2006, 2006 .

Kerkweg, A., Sander, R., Tost, H., and Jöckel, P.: Technical note: Implementation of prescribed (OFFLEM), calculated (ONLEM), and pseudo-emissions (TNUDGE) of chemical species in the Modular Earth Submodel System (MESSy), Atmos. Chem. Phys., 6, 3603-3609, doi:10.5194/acp-6-3603-2006, 2006b.

Kley, D., Crutzen, P. J., Smit, H. G. J., Vömel, H., Oltmans, S. J., Grassl, H., and Ramanathan, V.: Observations of near-zero ozone concentrations over the convective Pacific: Effects on air chemistry, Science, 274, 230-233, 1996.

Kokhanovsky, A. and Rozanov, V.: The uncertainties of satellite DOAS total ozone retrieval for a cloudy sky, Atmos. Res., 87, 27-36, 2008.

Lacis, A. A., Wuebbles, D. J., and Logan, J. A. A.: Radiative forcing of climate by changes in the vertical distributions of ozone, J. Geophys. Res., 95, 9971-9981, 1990.

Lamarque, J.-F., Bond, T. C., Eyring, V., Granier, C., Heil, A., Klimont, Z., Lee, D., Liousse, C., Mieville, A., Owen, B., Schultz, M. G., Shindell, D., Smith, S. J., Stehfest, E., Van Aardenne, J., Cooper, O. R., Kainuma, M., Mahowald, N., McConnell, J. R., Naik, V., Riahi, K., and van Vuuren, D. P.: Historical (1850-2000) gridded anthropogenic and biomass burning emissions of reactive gases and aerosols: methodology and application, Atmos. Chem. Phys., 10, 7017-7039, doi:10.5194/acp10-7017-2010, 2010.

Lambert, J. C., Granville J., Van Roozendael M., Sarkissian A., Goutail F., Müller J.-F., Pommereau J.-P., and Russell III, J. M.: A climatology of $\mathrm{NO}_{2}$ profile for improved air mass factors for ground-based vertical column measurements, Proceedings of the 5th European Symposium Strat. Ozone, Saint Jean de Luz, Sept 1999, Air pollution research report 73, European Commission, edited by: Harris NRP, Guirlet M, Amanatidis GT, 703 pp., ISBN 92 827-5672-6, 2000.

Lee, S., Shelow, D. M., Thompson, A. M., and Miller, S. K.: QBO and ENSO variability in temperature and ozone from SHADOZ, 1998-2005, J. Geophys. Res., 115, D18105, doi:10.1029/2009JD013320, 2010.

Levelt, P. F., van den Oord, G. H. J., Dobber, M. R., Mälkki, A., Visser, H., de Vries, J., Stammes, P., Lundell, J. O. V., and Saari, H.: The Ozone Monitoring Instrument, IEEE Trans. on Geosci. 
Rem. Sens., 44, 1093-1101, doi:10.1109/TGRS.2006.872333, 2006.

Liu, X., Bhartia, P. K., Chance, K., Spurr, R. J. D., and Kurosu, T. P.: Ozone profile retrievals from the Ozone Monitoring Instrument, Atmos. Chem. Phys., 10, 2521-2537, doi:10.5194/acp-10-25212010, 2010.

Loyola, D., Thomas, W., Livschitz, Y., Ruppert, T., Albert, P., and Hollmann, R.: Cloud properties derived from GOME/ERS-2 backscatter data for trace gas retrieval, IEEE Trans. Geosci. Remote Sens., 45, 2747-2758, 2007.

Loyola, D., Coldewey-Egbers, M., Dameris, M., Garny, H., Stenke, A., Van Roozendael, M., Lerot, C., Balis, D., and Koukouli, M.: Global long-term monitoring of the ozone layer - a prerequisite for predictions, Int. J. Remote Sensing, 30, 4295-4318, doi:10.1080/01431160902825016, 2009.

Loyola, D., Thomas, W., Spurr, R., and Mayer, B.: Global patterns in daytime cloud properties derived from GOME backscatter UV-VIS measurements, Int. J. Remote Sens., 31, 4295-4318, 2010.

Loyola, D., Koukouli, M. E., Valks, P., Balis, D. S., Hao, N., Van Roozendael, M., Spurr, R. J. D., Zimmer, W., Kiemle, S., Lerot, C., and Lambert, J.-C.: The GOME-2 total column ozone product: Retrieval algorithm and ground-based validation, J. Geophys. Res., 116, D07302, doi:10.1029/2010JD014675, 2011.

Malicet, C., Daumont, D., Charbonnier, J., Parisse, C., Chakir, A., and Brion, J.: Ozone UV spectroscopy, II. Absorption crosssections and temperature dependence, J. Atmos. Chem., 21, 263273, 1995.

Martin, R. V., Sauvage, B., Folkins, I., Sioris, C. E., Boone, C., Bernath, P., and Ziemke, J.: Space-based constraints on the production of nitric oxide by lightning, J. Geophys. Res., 112, D09309, doi:10.1029/2006JD007831, 2007.

McPeters, R. D., Labow, G. J., and Logan, J. A.: Ozone climatological profiles for satellite retrieval algorithms, J. Geophys. Res., 112, D05308, doi:10.1029/2005JD006823, 2007.

Miles, G. M., Siddans, R., Kerridge, B. J., Latter, B. G., and Richards, N. A. D.: Tropospheric ozone and ozone profiles retrieved from GOME-2 and their validation, Atmos. Meas. Tech. Discuss., 7, 7923-7962, doi:10.5194/amtd-7-7923-2014, 2014.

Munro, R., Eisinger, M., Anderson, C., Callies, J., Corpaccioli, E., Lang, R., Lefebvre, A., Livschitz, Y., and Perez Albinana, A.: GOME-2 on MetOp: From in-orbit verification to routine operations, in: Proceedings of EUMETSAT Meteorological Satellite Conference, Helsinki, Finland, 12-16 June 2006.

Oman, L., Ziemke, J., Douglass, A., Waugh, D., Lang, C., Rodriguez, J., and Nielsen, J.: The response of tropical tropospheric ozone to ENSO, Geophys. Res. Lett., 38, L13706, doi:10.1029/2011GL047865, 2011.

Oman, L., Douglass, A., Ziemke, J., Rodriguez, J., Waugh, D., and Nielsen, J.: The ozone response to ENSO in Aura satellite measurements and a chemistry-climate simulation, J. Geophys. Res., 118, 965-976, doi:10.1029/2012JD018546, 2013.

Platt, U. and Stutz, J.: Differential Optical Absorption Spectroscopy, Principles and Applications, Springer, Phys. Earth Space Environ., ISBN 978-3-540-21193-8, 2008.

Pozzer, A., Jöckel, P., Tost, H., Sander, R., Ganzeveld, L., Kerkweg, A., and Lelieveld, J.: Simulating organic species with the global atmospheric chemistry general circulation model ECHAM5/MESSy1: a comparison of model results with obser- vations, Atmos. Chem. Phys., 7, 2527-2550, doi:10.5194/acp-72527-2007, 2007.

Rex, M., Wohltmann, I., Ridder, T., Lehmann, R., Rosenlof, K., Wennberg, P., Weisenstein, D., Notholt, J., Krüger, K., Mohr, V., and Tegtmeier, S.: A tropical West Pacific $\mathrm{OH}$ minimum and implications for stratospheric composition, Atmos. Chem. Phys., 14, 4827-4841, doi:10.5194/acp-14-4827-2014, 2014.

Roeckner, E., Brokopf, R., Esch, M., Giorgetta, M., Hagemann, S., Kornblueh, L., Manzini, E., Schlese, U., and Schulzweida, U.: Sensitivity of simulated climate to horizontal and vertical resolution in the ECHAM5 atmosphere model, J. Climate, 19, 37713791, 2006.

Rossow, W. B. and Schiffer, R. A.: Advances in understanding clouds from ISCCP, Bull. Am. Meteor. Soc., 80, 2261-2287, 1999.

Safieddine S., Clerbaux, C., George, M., Hadji-Lazaro, J., Hurtmans, D., Coheur, P.-F., Wespes, C., Loyola, D., Valks, P., and Hao, N.: Tropospheric ozone and nitrogen dioxide measurements in urban and rural regions as seen by IASI and GOME-2, J. Geophys. Res., 118, 10555-10566, 2013.

Sander, R., Baumgaertner, A., Gromov, S., Harder, H., Jöckel, P., Kerkweg, A., Kubistin, D., Regelin, E., Riede, H., Sandu, A., Taraborrelli, D., Tost, H., and Xie, Z.-Q.: The atmospheric chemistry box model CAABA/MECCA-3.0, Geosci. Model Dev., 4, 373-380, doi:10.5194/gmd-4-373-2011, 2011.

Sauvage, B., Martin, R. V., van Donkelaar, A., and Ziemke, J. R.: Quantification of the factors controlling tropical tropospheric ozone and the South Atlantic maximum, J. Geophys. Res., 112, D11309, doi:10.1029/2006JD008008, 2007.

Schoeberl, M. R., Ziemke, J. R., Bojkov, B., Livesey, N., Duncan, B., Strahan, S., Froidevaux, L., Kulawik, S., Bhartia, P. K., Chandra, S., Levelt, P. F., Witte, J. C., Thompson, A. M., Cuevas, E., Redondas, A., Tarasick, D. W., Davies, J., Bodeker, G., Hansen, G., Johnson, B. J., Oltmans, S. J., VÖmel, H., Allaart, M., Kelder, H., Newchurch, M., Godin-Beekmann, S., Ancellet, G., Claude, H., Andersen, S. B., Kyrö, E., Parrondos, M., Yela, M., Zablocki, G., Moore, D., Dier, H., von der Gathen, P., Viatte, P., Stübi, R., Calpini, B., Skrivankova, P., Dorokhov, V., de Backer, H., Schmidlin, F. J., Coetzee, G., Fujiwara, M., Thouret, V., Posny, F., Morris, G., Merrill, J., Leong, C. P., Koenig-Langlo, G., and Joseph, E.: A trajectory-based estimate of the tropospheric ozone column using the residual method, J. Geophys. Res., 112, D24S49, doi:10.1029/2007JD008773, 2007.

Siddans, R., Latter, B. G., Kerridge, B. J., Smeets, J., Otter, G., and Slijkhuis, S.: Analysis of GOME-2 Slit function Measurements: Final Report Eumetsat Contract No. EUM/CO/04/1298/RM, 2006.

Solomon, S., Thompson, D. W. J., Portmann, R. W., Oltmans, S. J., and Thompson, A. M.: On the distribution and variability of ozone in the tropical upper troposphere: Implications for tropical deep convection and chemical-dynamical coupling, Geophys. Res. Lett., 32, L23813, doi:10.1029/2005GL024323, 2005.

Spurr, R.: LIDORT and VLIDORT: Linearized pseudo-spherical scalar and vector discrete ordiate radiative transfer models for use in remote sensing retrieval problems, Light Scattering Reviews, edited by: Kokhanovsky, A., Vol. 3, Springer, 2008.

Thompson, A. M.: The oxidizing capacity of the earth's atmosphere: Probable past and future changes, Science 256, 1157$1165,1992$. 
Thompson, A. M., Witte, J. C., Hudson, R. D., Guo, H., Herman, J. R., and Fujiwara, M.: Tropical tropospheric ozone and biomass burning, Science, 291, 2128-2132, 2001.

Thompson, A. M., Witte, J. C., McPeters, R. D., Oltmans, S. J., Schmidlin, F. J., Logan, J. A., Fujiwara, M., Kirchhoff, V. W. J. H., Posny, F., Coetzee, G. J. R., Hoegger, B., Kawakami, S., Ogawa, T., Johnson, B. J., Vömel, H., and Labow, G.: Southern Hemisphere Additional Ozonesondes (SHADOZ) 1998-2000 tropical ozone climatology: 1. Comparison with Total Ozone Mapping Spectrometer (TOMS) and ground-based measurements, J. Geophys. Res., 108, 8238, doi:10.1029/2001JD000967, 2003a.

Thompson, A. M., Witte, J. C., Oltmans, S. J., Schmidlin, F. J., Logan, J. A., Coetzee, G. J. R., Hoegger, B., Kirchhoff, V. W. J. H., Ogawa, T., Kawakami, S., Posny, F., Fortuin, J. P. F., Kelder, H. M., and Fujiwara, M.: Southern Hemisphere Additional Ozonesondes (SHADOZ) 1998-2000 tropical ozone climatology: 2. Tropospheric variability and the zonal wave-one, J. Geophys. Res., 108, 8241, doi:10.1029/2002JD002241, 2003 b.

Tost, H., Jöckel, P., Kerkweg, A., Sander, R., and Lelieveld, J.: Technical note: A new comprehensive SCAVenging submodel for global atmospheric chemistry modelling, Atmos. Chem. Phys., 6, 565-574, doi:10.5194/acp-6-565-2006, 2006.

Tuinder, O., van Oss, R., de Haan, J., and Delcloo, A.: Algorithm Theoretical Basis Document for the NRT and Off-line GOME-2 Ozone Profile Products, O3MSAF/KNMI/ATBD/001, Iss.1.15, available at: http://o3msaf.fmi.fi/docs/atbd/Algorithm_ Theoretical_Basis_Document_NOP_OOP_Jun_2013.pdf (last access: 24 January 2014), June 2013.

Valks, P. J. M., Koelemeijer, R. B. A., van Weele, M., van Velthoven, P., Fortuin, J. P. F., and Kelder, H.: Variability in tropical tropospheric ozone: Analysis with Global Ozone Monitoring Experiment observations and a global model, J. Geophys. Res., 108, 4328, doi:10.1029/2002JD002894, 2003.

Valks, P., Pinardi, G., Richter, A., Lambert, J.-C., Hao, N., Loyola, D., Van Roozendael, M., and Emmadi, S.: Operational total and tropospheric NO2 column retrieval for GOME-2, Atmos. Meas. Tech., 4, 1491-1514, doi:10.5194/amt-4-1491-2011, 2011.

Valks, P., Loyola, D., Hao, N., Rix, M., and Slijkhuis, S.: Algorithm Theoretical Basis Document for GOME-2 Total Column Products of Ozone, Minor Trace Gases and Cloud Properties (GDP 4.7 for O3M-SAF OTO and NTO), DLR/GOME-2/ATBD/01, Iss./Rev.: 2/H, available at: http://o3msaf.fmi.fi/docs/atbd/Algorithm_Theoretical_Basis_ Document_NTO_OTO_May_2013.pdf (last access: 24 January 2014), May 2013.

van der Werf, G. R., Randerson, J. T., Giglio, L., Collatz, G. J., Mu, M., Kasibhatla, P. S., Morton, D. C., DeFries, R. S., Jin, Y., and van Leeuwen, T. T.: Global fire emissions and the contribution of deforestation, savanna, forest, agricultural, and peat fires (19972009), Atmos. Chem. Phys., 10, 11707-11735, doi:10.5194/acp10-11707-2010, 2010.
Van Roozendael, M., Loyola, D., Spurr, R., Balis, D., Lambert, JC., Livschitz, Y., Valks, P., Ruppert, T., Kenter, P., and Fayt, C.: Reprocessing the 10-year GOME/ERS-2 total ozone record for trend analysis: the new GOME Data Processor Version 4.0, Algorithm Description, J. Geophys. Res., 111, D14311, doi:10.1029/2005JD006375, 2006.

Waliser, D. E. and Gautier, C.: A Satellite-derived Climatology of the ITCZ, J. Climate, 6, 2162-2174, 1993.

Waters, J. W., Froidevaux, L., Harwood, R. S., Jarnot, R. F., Pickett, H. M., Read, W. G., Siegel,P. H., Cofield, R. E., Filipiak, M. J., Flower, D. A., Holden, J. R., Lau, G. K., Livesey, N. J., Manney, G. L., Pumphrey, H. C., Santee, M. L., Wu, D. L., Cuddy, D. T., Lay, R. R., Loo, M. S., Perun, V. S., Schwartz, M. J., Stek, P. C., Thurstans, R. P., Boyles, M. A., Chandra, K. M., Chavez, M. C., Chen, G.-S., Chudasama, B. V., Dodge, R., Fuller, R. A., Girard, M. A., Jiang, J. H., Jiang, Y., Knosp, B. W., LaBelle, R. C., Lam, J. C., Lee, K. A., Miller, C., Oswald, J. E., Patel, N. C., Pukala, D. M., Quintero, O., Scaff, D. M., Van Snyder, W., Tope, M. C., Wagner, P. A., and Walch, M. J.: The Earth Observing System Microwave Limb Sounder (EOS MLS) on the Aura satellite, IEEE Trans. Geosci. Remote Sens., 44, 1075-1092, 2006.

Ziemke, J. R., Chandra, S., and Bhartia, P. K.: Two new methods for deriving tropospheric column ozone from TOMS measurements: The assimilated UARS MLS/HALOE and convective-cloud differential techniques, J. Geophys. Res., 103, 22115-22127, 1998.

Ziemke, J. R., Chandra, S., and Bhartia, P. K.: A 25-year data record of atmospheric ozone in the Pacific from Total Ozone Mapping Spectrometer (TOMS) cloud slicing: Implications for ozone trends in the stratosphere and troposphere, J. Geophys. Res., 110, D15105, doi:10.1029/2004JD005687, 2005.

Ziemke, J. R., Chandra, S., Duncan, B. N., Froidevaux, L., Bhartia, P. K., Levelt, P. F., and Waters, J. W.: Tropospheric ozone determined from Aura OMI and MLS: Evaluation of measurements and comparison with the Global Modeling Initiative's Chemical Transport Model, J. Geophys. Res., 111, D19303, doi:10.1029/2006JD007089, 2006.

Ziemke, J. R., Joiner, J., Chandra, S., Bhartia, P. K., Vasilkov, A., Haffner, D. P., Yang, K., Schoeberl, M. R., Froidevaux, L., and Levelt, P. F.: Ozone mixing ratios inside tropical deep convective clouds from OMI satellite measurements, Atmos. Chem. Phys., 9, 573-583, doi:10.5194/acp-9-573-2009, 2009a.

Ziemke, J. R., Chandra, S., Duncan, B. N., Schoeberl, M. R., Torres, O., Damon, M. R., and Bhartia, P. K.: Recent biomass burnings in the tropics and related changes in tropospheric ozone, Geophys. Res. Lett., 36, L15819, doi:10.1029/2009GL039303, 2009b.

Ziemke, J. R., Chandra, S., Oman, L. D., and Bhartia, P. K., A new ENSO index derived from satellite measurements of column ozone, Atmos. Chem. Phys., 10, 3711-3721, 2010, http://www.atmos-chem-phys.net/10/3711/2010/. 